Article

\title{
Evaluation of the Air Oxygen Enrichment Effects on Combustion and Emissions of Natural Gas/Diesel Dual-Fuel Engines at Various Loads and Pilot Fuel Quantities
}

\author{
Roussos G. Papagiannakis ${ }^{1}$, Dimitrios C. Rakopoulos ${ }^{2}$ and Constantine D. Rakopoulos ${ }^{2, *}$ \\ 1 Thermodynamic \& Propulsion Systems Section, Aeronautical Sciences Department, Hellenic Air Force \\ Academy, Dekelia Air Force Base, 1010 Dekelia, Attiki, Greece; r.papagiannakis@gmail.com \\ 2 Internal Combustion Engines Laboratory, Department of Thermal Engineering, School of Mechanical \\ Engineering, National Technical University of Athens, Zografou Campus, 9 Heroon Polytechniou Street, \\ 15780 Athens, Greece; dimracop@central.ntua.gr \\ * Correspondence: cdrakops@central.ntua.gr; Tel.: +30-210-772-3529
}

Received: 2 October 2018; Accepted: 1 November 2018; Published: 4 November 2018

check for updates

\begin{abstract}
The use of natural gas (NG) as supplement of the normal diesel fuel in compression ignition (CI) environments (Natural Gas/Diesel Dual-Fuel, NG/DDF), seems to present an answer towards reducing soot or particulate matter (PM) and nitrogen oxides (NOx) emissions in existing and future diesel engine vehicles. The benefits for the environment can be even higher, as recently NG quality gas can be produced from biomass (bio-methane or bio-CNG or 'green gas'). However, this engine type where the main fuel is the gaseous one and the diesel liquid fuel constitutes the ignition source (pilot), experiences higher specific energy consumption (SEC), carbon monoxide (CO), and unburned hydrocarbons (HC) emissions compared to the conventional (normal) diesel one, with these adverse effects becoming more apparent under partial load operation conditions. Apart from using bio-fuels as pilot fuel, it is anticipated that air oxygen enrichment-addition of oxygen in the intake air-can mitigate (at least partly) the associated negative results, by accelerating the burning rate and reducing the ignition delay. Therefore, the present work strives to investigate the effects of various degrees of oxygen enrichment on the combustion, performance, and emissions of such a NG/DDF engine, operated under various loads and pilot (diesel fuel) quantities. The study is carried out by using an in-house, comprehensive, computational model, which is a two-zone (phenomenological) one. The accuracy of the modeling results are tested by using related experimental data from the literature, acquired in an experimental investigation conducted on a naturally aspirated, light-duty, NG/DDF engine. The computational study is extended to include various pilot fuel quantities, attempting to identify the influence of the examined parameters and witness advantages and disadvantages. The study results demonstrate that the air oxygen enrichment reduces the specific energy consumption and $\mathrm{CO}$ emissions, by accelerating the burning rate and reducing the ignition delay (as revealed by the cylinder pressure and rate of heat release diagrams), without impairing seriously the soot and NO emissions. The conclusions of the specific investigation are much useful, particularly if wished to identify the optimum combination of the parameters under examination for improving the overall performance of existing CI engines functioning under natural gas/diesel fuel operating mode.
\end{abstract}

Keywords: intake air oxygen enrichment; natural gas; dual-fuel diesel engine; pilot fuel quantity; two-zone modeling; bio-fuels; combustion; performance; emissions 


\section{Introduction}

Strong motivation emanating from the necessity to advance both the performance and emission attributes of internal combustion engines, have forced scientists and engineers working in this arena to conceive and propose various technological solutions [1]. Such solutions include diverse techniques linked to either the design and operating engine conditions [2-6] or to the use of various types of alternative fuels, such as liquid bio-fuels [7-11] or gaseous fuels (e.g., natural gas) [12-16]. A number of gaseous fuels such as natural gas, liquefied petroleum gas (LPG), hydrogen, biogas, coal gas, and methanol, are considered as good alternative fuels for cars, trucks or stationary engines applications, as they accomplish several of the critical requirements of a fuel, such as abundance, domestic availability, non-expensive energy, safety in use, clean combustion, etc.

Natural gas (NG) has the potential to meet many of the above requirements. The basic chemical component of NG is methane $\left(\mathrm{CH}_{4}\right)$, mixed with lower concentrations of other low molecular-weight aliphatic hydrocarbon compounds, such as ethane, isomers of propane, butane and pentane in traces. Since its key component is methane (more than 90\%) it can also be produced synthetically. Moreover and more importantly, nowadays NG quality gas can be produced from various biomass feedstocks [17-20], hence increasing its eco-friendly merits, with this gas called bio-methane or biocompressed natural gas (CNG) or 'green gas'.

Natural Gas/Diesel Dual-Fuel (NG/DDF) engines are one of the most attractive short-term answers to mitigate emissions from conventional diesel engines, influenced by the $\mathrm{PM}-\mathrm{NOx}$ trade-off [21,22], while employing an alternative fuel or bio-fuel like NG as the main fuel [23,24]. Therefore, this results to an appealing technology for meeting the regulated emissions of the future and also a viable technique for retrofitting existing engines, with the purpose of ameliorating the global environmental impact.

A variety of techniques has been pursued for mitigating the pollutants emitted from internal combustion engines [21,22], which can be classified largely as: (i) Upgrading of engine design and in-cylinder strategies also named 'internal measures', by apposite setting (usually optimized) of operation parameters; (ii) Addition of after-treatment devices at the engine exhaust also named 'external measures', as e.g., three-way catalysts, oxidation catalysts, nitric oxide (NO) catalysis, particulate filters; and (iii) Practices related to selection of alternative to conventional fuels leading to pollutant emissions decrease, for instance in diesel engines by mitigating the smoke emissions via augmentation of the oxygen availability in the diesel combustion cylinders [25], while making efforts to maintain low the often attendant NOx emissions. For example, an effective means for reducing NOx, which belongs to the first category of the above internal measures, is the using of exhaust gas recirculation (EGR) [26].

The above third category is implemented in practice either by increasing the oxygen mass fraction of the aspirated air in the engine or by combusting oxygenated fuels [27-31]. The practical viability of oxygen enrichment for internal combustion engines depends on the availability of a simple compact mechanical system, driven by the engine itself. Apart from the traditional cryogenic method of extracting oxygen, the use of separation membranes is a known methodology for non-cryogenic separation of oxygen from the atmospheric air. The specific technology is not an economical solution yet, but continuous development in membrane separation techniques may render this option economically viable in the future, and this is why this technique is worth investigating further. The latter technique is realized by using oxygenates in fuel blends, such as mostly biofuels like plant oils, biodiesels, ethanol, $n$-butanol, and diethyl ether (DEE) in conventional diesel engines, as e.g., communicated in recent review type papers by the authors [32-35].

In a conventional NG/DDF engine, the primary fuel, which is natural gas, is mixed with air in the intake manifold. The mixture is then compressed and subsequently ignited by the combustion of a small mass of liquid diesel fuel (pilot fuel), which is injected into the engine cylinder as the piston comes close to top dead center (TDC) position. The use of very lean mixtures combined with the high octane number possessed by the natural gas (NG), contributes to the avoidance of the easy 
incipience of knock in dual fuel (natural gas-diesel) operation. It is for this reason that the use of NG as primary fuel permits one to maintain the normal (high) compression ratio (CR) of the diesel engine, from which a NG/DDF engine emanated. Thus, existing conventional diesel engines can be transformed into dual-fuel operation without much modification. NG/DDF engines have been used in several mobile sources such as e.g., vehicles, trucks, buses, locomotives, marine ships and agricultural machinery [14,23].

The international literature on the subject reveals that NG/DDF engines possess a notable potential to decrease $\mathrm{PM}$ and $\mathrm{NO}$ emissions from the corresponding baseline diesel engine case $[14,15,23,24]$. PM emissions can drop with the replacement of a high amount of diesel fuel by NG, as the combustion of a homogeneous lean charge minimizes the local peaks of temperature and hence the NO amounts in the exhaust gases. Since the majority of NG/DDF engines are functioning usually without throttle (i.e., the load is controlled by the amount of natural gas inlet in the intake manifold), the air-fuel mixture turns out to be much leaner as the load decreases, hence approaching the lean limit of mixture flammability. Therefore in this case the consequent combustion process is slow, leading to creation of incomplete combustion products of the regulated emissions of unburned hydrocarbons ( $\mathrm{HC}$ ) and carbon monoxide (CO). Moreover, the raise in $\mathrm{CO}$ emissions is also attributed to the local mixture enrichment, because the injected (pilot) diesel fuel mixes with a homogeneous NG-air mixture instead of simply air. Further, added reasons for the higher HC exhaust emissions are the scavenging process and the cylinder crevice volume action, as these processes entail now NG-air mixture instead of simply air $[21,22]$.

The increased specific energy consumption (SEC) (and corresponding reduction in efficiency) and the elevated emissions under part load operations, together with the knock inception at high loads (an unavoidable fact for mixtures close to stoichiometric conditions), represent the principal drawbacks of NG/DDF engines. Many potential solutions have been devised and studied to ameliorate the behavior of NG/DDF engines, especially under part load operating conditions. These comprise, among others, the following: (a) Optimization of the liquid diesel fuel injection attributes, e.g., via the change of the amount or/and the pressure or/and the timing of the liquid diesel fuel, and (b) Variation of the amount of the cylinder charge (NG-air mixture) at the inlet valve closing event, e.g., via the change of inlet pressure (i.e., by varying the boost pressure or by using intake throttling) or/and of inlet temperature (e.g., inlet air preheating).

A sizeable research effort on NG/DDF has focused on investigating dual-fueling and its influence on performance and emitted pollutants. A diversity of theoretical and experimental investigations have appeared in the literature examining the relative effects of each one of several important engine parameters, like for example quantity (mass) of diesel fuel and injection timing, preheating of inlet air, recirculation of exhaust gas (EGR), etc. [36-43].

In contrast to the above, the investigation/evaluation of the effects of intake air oxygen enrichment in NG/DDF engines on their combustion, performance, and emissions is limited to less than a handful of experimental investigations (even covering few aspects) [44,45], while no such computational study exists in the international literature. The air-inlet oxygen enrichment seems to be one of the attractive combustion technologies to control pollution and improve combustion quality in a compression ignition environment. Specifically, the use of oxygen enriched inducted air, is one method that seems to affect positively (reduce) $\mathrm{CO}, \mathrm{HC}$ and soot emissions, while it also improves the total brake specific energy consumption of a compression ignition engine operating under natural gas/diesel dual fuel mode.

Therefore, the present study attempts to fill this apparent gap by implementing, for the above case, a comprehensive, in-house, phenomenological, two-zone model of combustion, which has been presented and tested successfully by the authors in the past [46-49]. The model is validated against the available sparse experimental data and then extended to include also the influence of various pilot diesel fuel quantities (an important parameter), attempting to identify the effects of the examined parameters and record advantages and disadvantages. Cylinder pressure and rate of heat release 
diagrams provide insight into the physical and chemical mechanisms governing the operation under various degrees of oxygen enrichment of the NG/DDF engine, running under various load and pilot fuel quantity conditions, providing useful conclusions to identify the optimum combination of the parameters under examination. To the best of the authors' knowledge, such a study has not been reported to present.

It is stated that several works in NG/DDF engines exist using bio-fuels (like biodiesel) in the pilot fuel [50-53] as a counterpart method of the air oxygen enrichment, so that the comparative evaluation of their pros and cons would form an interesting study, which is however deferred by the present group for a near-future communication.

\section{Short Outline of the Simulation Model}

The simulation model used in this work is founded on an existing phenomenological, two-zone model of combustion developed by the first author in the past, which examines the closed part of a NG/DDF engine cycle [46-49]. Therefore, in the present paper solely the basic details of the model are provided, with its philosophy depicted in the flow chart diagram presented in Figure 1.

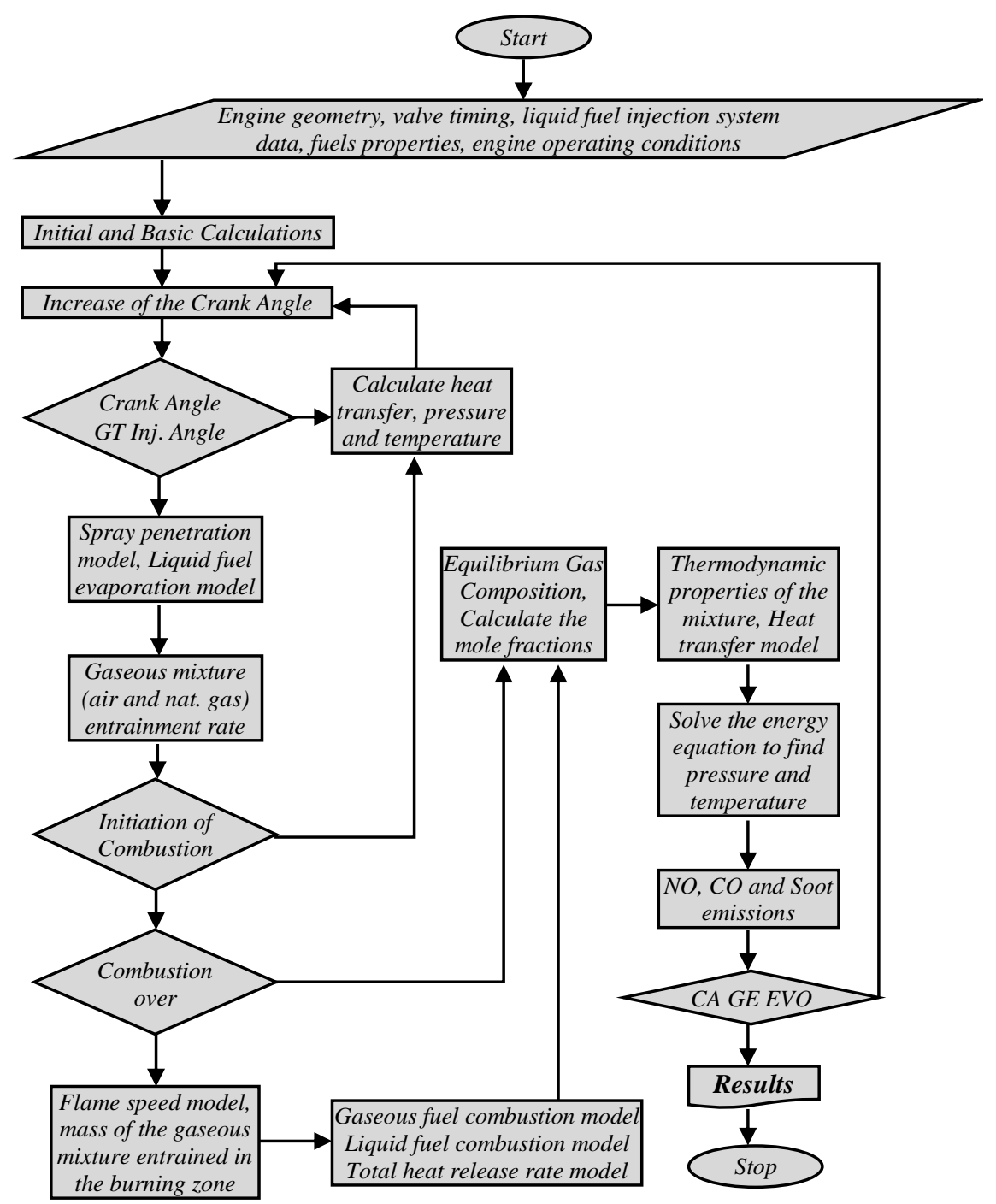

Figure 1. Flow chart diagram of the simulation model.

The model in question is used to describe the operation of NG/DDF engines, where the main part of the (liquid) diesel fuel is replaced by NG, which is fumigated into the aspirated air during the 
induction process. The model uses the fundamental conservation laws of thermodynamics: mass, momentum, and energy. These are applied individually for each one of the zones, and then for the whole charge of the engine cylinder. According to the modeling, the newly entering charge of the inletting mixture (NG-air) is presumed to be at the start homogeneous and completely mixed up all through the induction stroke. After the intake valve closing (IVC) event, the mixture is compressed, burned, and in the end expanded during the expansion stroke. Gas leakage via crevices from the cylinder during the closed part of the cycle is assumed insignificant, and all mixture components are treated as ideal gases.

Throughout the compression stroke, the cylinder charge (a gaseous mixture of fuel and air) is considered and treated as a single-zone (unburned zone), with the hypothesis of spatial uniformity of pressure, temperature, and gas composition. A little prior to reaching TDC position, a small mass of liquid diesel fuel is injected into the combustion chamber. The injected liquid fuel forms a conical jet that pierces into the unburned zone [54]. The borders of this conical jet enclose the burning zone. The charge ignition in the burning zone initiates as a follow up of the evaporated liquid-fuel auto-ignition. Thus, the period of ignition delay is defined as the time interval between the commencement of liquid fuel injection and the initiation of combustion. The prediction of diesel fuel ignition delay period depends on a constant parameter $\left(\mathrm{C}_{\mathrm{ID}}\right)$, which, in the present work, was defined equal to 0.000612 . During this period, the burning zone is regarded to possess a conical shape, while at the initiation of combustion its shape is assumed to be converted into a spherical one, with the corresponding volumes being equalized. Therefore, during the combustion process, the external boundary of the burning zone is outlined by the flame front. The spread of the latter inside the unburned zone is dictated by the flame speed, which is computed by using the turbulent flame propagation mechanism described by Blizard and Keck [55]. The flame front thickness is considered very thin and the cylinder pressure identical inside the burned and unburned zones.

For the estimation of the preparation and combustion rates of the liquid diesel fuel, use is made of the semi-empirical combustion model of Whitehouse and Way [56]. Both the preparation and the combustion rates of the liquid diesel fuel are controlled by two constants $\left(\mathrm{C}_{\operatorname{Pr}, \mathrm{D}}, \mathrm{C}_{\mathrm{Comb}, \mathrm{D}}\right)$, which, in the present work, were defined equal to 0.26 and $0.39 \times 10^{6}$, respectively. The rate of combustion of the gaseous fuel depends on the flame front spread, while the amount of gaseous fuel entrained inside the burning zone is converted right away into products. Moreover, the rate of combustion of the gaseous fuel entrained inside the burning zone during the period of ignition delay is controlled by a reaction rate of Arrhenius type [57]. The estimation of the gaseous fuel combustion rate due to the spread of the flame front is controlled by a constant parameter equal to $C_{\mathrm{Flame}, \mathrm{NG}}=0.35$, while the second combustion rate is controlled by a constant parameter $\left(\mathrm{C}_{\mathrm{Arrh}, \mathrm{NG}}\right)$, which, in the present work, was defined equal to $0.98 \times 10^{6}$.

The rate of heat transfer from each one of the zones to the combustion chamber walls is calculated by using the formula of Annand [58]. According to this formula, the rate of heat transfer is controlled by three constant parameters $\left(C_{A n n 1}, C_{A n n 2}, C_{A n n 3}\right)$, which, in the present study, were defined equal to $0.16,0.15$ and 0.0000011 , respectively. Details for the estimation of the rate of diesel fuel injection are given in [46,47]. The method of Vickland et al. [59] is adopted for calculating the dissociation of combustion products. The NO formation and oxidation rates are simulated by using the extended Zeldovich chemical reactions mechanism [60]. Furthermore, it is assumed that the CO produced by the combustion process is oxidized to $\mathrm{CO}_{2}$ at a rate slower as compared to the formation rate of $\mathrm{CO}$, with more details about the estimation of the net formation rate of $\mathrm{CO}$ given in [47]. Finally, the mathematical (semi-empirical) formula by Hiroyasu et al. [54] is implemented to simulate the soot formation mechanism, by taking into consideration details pertained to the cylinder pressure, temperature of the burning zone, concentrations of oxygen, and the unburned liquid fuel in the burning zone [48,49]. 


\section{Validation of the Model}

As exposed in the preceding section, the model used herein is an existing in-house, phenomenological, two-zone combustion model, simulating the closed part of the operating cycle of natural gas-diesel dual fuel (NG/DDF) engines. The basic philosophy of the model was not modified for the needs of the present study, but care was exerted for inclusion of various oxygen contents of the aspirated air. The data of the only relatively complete experimental investigation in [44] were used here, solely to calibrate and moreover evaluate the predictive capabilities of the model.

It concerns a single cylinder, 4-stroke, water cooled, naturally aspirated, direct injection (DI) diesel engine, having a bowl-in-piston combustion chamber, converted to operate in natural gas-diesel dual fuel (NG/DDF) mode. The basic geometrical and operation data associated with the simulated engine are given in Table 1, where CA means crank angle and BDC means bottom dead center. The basic characteristics of the liquid diesel fuel and the natural gas used are shown in Table 2 [44], where the NG contained $91 \%$ by vol. methane $\left(\mathrm{CH}_{4}\right)$ and lower concentrations of ethane, propane, butane and pentane in traces. It is noted, as mentioned previously, that nowadays such NG quality gas (containing mainly methane) can be produced from various biomass feedstocks, hence increasing its eco-friendly virtues (with this gas called bio-methane or bio-CNG or 'green gas').

Table 1. Basic geometrical and operational data of the test engine [44].

\begin{tabular}{cc}
\hline Engine & Petter PH1W \\
\hline Type & Single cylinder, \\
\hline Number of cylinders & 1 \\
Cylinder bore $(\mathrm{m})$ & 0.087 \\
Piston stroke $(\mathrm{m})$ & 0.100 \\
Compression ratio & $16.5: 1$ \\
Rated Power $(\mathrm{kW}) /$ Speed (rpm) & $6.15 / 2000$ \\
Fuel injection system & Direct injection (DI) \\
Number of nozzle holes & 3 \\
Injection pressure (bar) & 200 \\
Static injection timing & 28 degCA before TDC \\
Inlet valve opening (IVO) & $4.5 \mathrm{degCA}$ before TDC \\
Inlet valve closure (IVC) & $35.5 \mathrm{degCA}$ after BDC \\
Exhaust valve opening (EVO) & $35.5 \mathrm{degCA}$ before BDC \\
Exhaust valve closure (EVC) & $4.5 \mathrm{degCA}$ after TDC \\
\hline
\end{tabular}

Table 2. Basic characteristics of the fuels used [44].

\begin{tabular}{cccc}
\hline Property & Unit & Diesel Fuel & Natural Gas \\
\hline Chemical formula & - & $\mathrm{C}_{10.8} \mathrm{H}_{18.7}$ & $\mathrm{C}_{1.16} \mathrm{H}_{4.32}$ \\
Density @ 1 bar and 20 deg C & $\mathrm{kg} / \mathrm{m}^{3}$ & 830 & 0.695 \\
Lower heating value & $\mathrm{MJ} / \mathrm{kg}$ & 43 & 49 \\
Laminar flame speed & $\mathrm{m} / \mathrm{s}$ & 0.05 & 0.34 \\
Octane number & - & $\mathrm{n} / \mathrm{a}$ & 120 \\
Cetane number & - & 52 & $\mathrm{n} / \mathrm{a}$ \\
Stoichiometric air-fuel ratio & $\mathrm{kg} / \mathrm{kg}$ & 14.3 & 16.8 \\
\hline
\end{tabular}

The intake system of the engine consists of a specially-designed mixing device, in which a complete mixing takes place among the engine aspirated air, the enrichment oxygen, and the gaseous fuel (NG). Then, the homogeneous mixture formed in the mixing device flows into the cylinder due to the engine suction effect. The NG was supplied in the mixing device from high pressure commercial CNG bottles (200 bar), using a three-stage pressure regulator to reduce-down pressure at a little lower than atmospheric pressure. The appropriate mass flow rate of oxygen enrichment was achieved by using compressed oxygen bottles outfitted with pressure regulating and control valves, which was measured by a suitable thermal mass flowmeter. 
According to the type of engine tested herein, when it operates at constant engine speed under normal diesel operating (NDO) mode, the mass flow rate of the inducted air corresponding to the inlet valve closing event is estimated as:

$$
\left(\mathrm{m}^{\prime}{ }_{\mathrm{air}, \mathrm{IVC}}\right)_{\mathrm{NDO}}=\eta_{\mathrm{V}} \times \rho_{\mathrm{a}} \times\left(\mathrm{V}^{\prime}\right)_{\mathrm{h}}
$$

where, $\left(\eta_{\mathrm{V}}\right)$ represents the engine volumetric efficiency, $\left(\mathrm{V}^{\prime}\right)_{\mathrm{h}}$ is the engine swept volume flow rate, and $\left(\rho_{\mathrm{a}}\right)$ is the air density. When the engine operates at the same speed under natural gas-diesel dual fuel (NG/DDF) mode, the fumigated gaseous fuel displaces some of the fresh air inletting the combustion chamber. In this case, the mass flow rate of the gaseous fuel $\left(\mathrm{m}^{\prime} \mathrm{g}\right)$ can be estimated as:

$$
\left(\mathrm{m}_{\mathrm{g}}^{\prime}\right)=\left(\left(\mathrm{m}_{\mathrm{air}, \mathrm{IVC}}^{\prime}\right)_{\mathrm{NDO}}-\lambda_{\mathrm{tot}} \times \mathrm{AFR}_{\mathrm{d}, \mathrm{st}} \times\left(\mathrm{m}_{\mathrm{d}}^{\prime}\right)_{\mathrm{NG} / \mathrm{DDF}}\right) /\left(\lambda_{\mathrm{tot}} \times \mathrm{AFR}_{\mathrm{g}, \mathrm{st}}+1\right)
$$

where $\left(\lambda_{\text {tot }}\right)$ represents the total air to fuel excess ratio, $\left(\mathrm{AFR}_{\mathrm{d}, \mathrm{st}}, \mathrm{AFR}_{\mathrm{g}, \mathrm{st}}\right)$ denote the stoichiometric air to fuel ratio (by mass) for diesel and gaseous fuels respectively, and $\left(\mathrm{m}_{\mathrm{d}}{ }_{\mathrm{N}} \mathrm{NG}_{\mathrm{DDF}}\right.$ represents the pilot diesel fuel mass flow rate. In this study, the amount of the pilot diesel fuel is expressed as a percentage $(\mathrm{a} \%)$ of the rated value observed under normal diesel engine operating mode (NDO), i.e.:

$$
\left(\mathrm{m}_{\mathrm{d}}^{\prime}\right)_{\mathrm{NG} / \mathrm{DDF}}=(\mathrm{a} \% / 100) \times\left(\mathrm{m}_{\mathrm{d}}^{\prime}\right)_{\mathrm{NDO}}
$$

It must be stated here that the stoichiometric air to fuel ratio $\left(\mathrm{AFR}_{\mathrm{st}}\right)$ and the lower heating value for each one of the fuels used herein are computed by knowing the chemical composition of fuels.

According to [44], the experimental results used in that study correspond to NG/DDF operating mode, under constant engine speed (i.e., $\mathrm{N}=1600 \mathrm{rpm}$ ), at $43 \%$ and $96 \%$ of the engine rated load, for constant diesel fuel injection timing, i.e., DIT $=165 \mathrm{degCA}$. It should also be stated that for both engine operating points, the pilot diesel fuel mass was kept constant at a ratio of $20 \%$ (i.e., a $=20 \%$ ) of the rated value observed under conventional diesel engine operation (i.e., "normal pilot fuel"), while the engine power was adjusted only through the natural gas quantity regulation. Furthermore, for each one of both engine operating points, three sets of experimental measurements were used. The first set corresponds to intake air charge containing (by vol.) $\mathrm{x}_{\mathrm{O} 2}=21 \%$ oxygen, which is understood to represent the "normal air" (i.e., "normal air" is assumed to contain $21 \%$, by volume, oxygen), while the other two sets correspond to intake air charge containing (by vol.) $\mathrm{x}_{\mathrm{O} 2}=23 \%$ and $\mathrm{x}_{\mathrm{O} 2}=25 \%$ oxygen, respectively. For each one of the three sets of measurements in question, use was made of the experimental data referring to the cylinder pressure and the total rate of heat release diagrams, the brake specific energy consumption (BSEC), the specific NO (spNO), CO (spCO) and Soot (spSoot) emissions. All these experimental data, derived from [44], were used as a basis for calibrating and evaluating the predictive capabilities of the proposed model and, furthermore, to appraise the theoretical findings concerning the effect of intake air oxygen enrichment on the performance characteristics and pollutant emissions of an existing light-duty, naturally aspirated, DI, compression ignition engine functioning under NG/DDF operating mode. Tables 3 and 4 summarize all the aforementioned experimental data, where $M_{\sigma}$ and $\mathrm{P}_{\mathrm{e}}$ denote engine brake torque and power respectively.

Table 3. Experimental data for NG/DDF engine operating mode with "normal pilot fuel" quantity, at $43 \%$ and $96 \%$ of engine rated load \& $1600 \mathrm{rpm}$ engine speed, for various " $\mathrm{x}_{\mathrm{O} 2}$ " ratios.

\begin{tabular}{ccccccccccc}
\hline \multirow{2}{*}{ Load } & \multirow{2}{*}{$\mathbf{M}_{\boldsymbol{\sigma}}$} & \multirow{2}{*}{$\mathbf{P}_{\mathbf{e}}$} & \multirow{2}{*}{} & \multirow{2}{*}{$\boldsymbol{\lambda}_{\text {tot }}$} & DIT & $\mathbf{m}_{\mathbf{d}}$ & $\mathbf{a}$ & \multicolumn{3}{c}{$\mathbf{m}_{\mathbf{g}}(\mathbf{k g} / \mathbf{h})$} \\
\cline { 7 - 11 } & & & & & & & & $\mathbf{x}_{\mathbf{O} 2}$ & $\mathbf{x}_{\mathbf{O} 2}$ & $\mathbf{x}_{\mathbf{O} 2}$ \\
\hline$(\%)^{1}$ & $\mathrm{Nm}$ & $\mathrm{kW}$ & $\mathrm{rpm}$ & - & $\mathrm{deg}$ CA BTDC & $\mathrm{kg} / \mathrm{h}$ & $\%$ & $\mathbf{2 1 \%}$ & $\mathbf{2 3 \%}$ & $\mathbf{2 5 \%}$ \\
\hline 43 & 12.54 & 2.10 & 1600 & 2.04 & 15 & 0.116 & 20 & 0.805 & 0.732 & 0.689 \\
96 & 28.02 & 4.69 & 1600 & 1.47 & 15 & 0.260 & 20 & 1.072 & 1.003 & 0.960 \\
\hline
\end{tabular}

1 percentage of the engine rated load; $\mathrm{m}_{\mathrm{d}}=$ diesel mass flow rate; $\mathrm{m}_{\mathrm{g}}=$ natural gas mass flow rate; $\lambda_{\text {tot }}=$ total air-fuel excess ratio; $a$ = pilot diesel fuel percentage of the rated value observed under NDO mode. 
Table 4. Experimental data for NG/DDF engine operating mode, with "normal pilot fuel" quantity, at $43 \%$ and $96 \%$ of engine rated load \& $1600 \mathrm{rpm}$ engine speed, for various " $\mathrm{xO}_{2}$ " ratios.

\begin{tabular}{ccccccccccccc}
\hline \multirow{2}{*}{ Load } & \multicolumn{3}{c}{ BSEC (g/kWh) } & \multicolumn{3}{c}{ NO (g/kWh) } & \multicolumn{3}{c}{ CO (g/kWh) } & \multicolumn{3}{c}{ Soot $(\mathrm{g} / \mathbf{k W h})$} \\
\cline { 2 - 12 } & $\mathbf{x}_{\mathbf{O} 2}$ & $\mathbf{x}_{\mathbf{O} 2}$ & $\mathbf{x}_{\mathbf{O} 2}$ & $\mathbf{x}_{\mathbf{O} 2}$ & $\mathbf{x}_{\mathbf{O} 2}$ & $\mathbf{x}_{\mathbf{O} 2}$ & $\mathbf{x}_{\mathbf{O} 2}$ & $\mathbf{x}_{\mathbf{O} 2}$ & $\mathbf{x}_{\mathbf{O} 2}$ & $\mathbf{x}_{\mathbf{O} 2}$ & $\mathbf{x}_{\mathbf{O} 2}$ & $\mathbf{x}_{\mathbf{O} 2}$ \\
\hline $\mathbf{( \% )}$ & $\mathbf{2 1 \%}$ & $\mathbf{2 3 \%}$ & $\mathbf{2 5 \%}$ & $\mathbf{2 1 \%}$ & $\mathbf{2 3 \%}$ & $\mathbf{2 5 \%}$ & $\mathbf{2 1 \%}$ & $\mathbf{2 3} \%$ & $\mathbf{2 5 \%}$ & $\mathbf{2 1 \%}$ & $\mathbf{2 3} \%$ & $\mathbf{2 5 \%}$ \\
\hline 43 & 21.17 & 19.45 & 18.46 & 2.8 & 4.5 & 6.1 & 31 & 27 & 25 & 0.00185 & 0.00127 & 0.00089 \\
96 & 13.58 & 12.85 & 12.41 & 3.6 & 4.9 & 5.9 & 7 & 5.5 & 6 & 0.00035 & 0.00018 & 0.00015 \\
\hline
\end{tabular}

In order to confirm the model's capability to predict both the cylinder pressure and total burning rate, Figure $2 \mathrm{a}, \mathrm{b}$ compare the computational and experimental cylinder pressure and total heat release rate curves, corresponding to NG/DDF engine operating mode with "normal pilot fuel" quantity, i.e., "a" $=20 \%$.

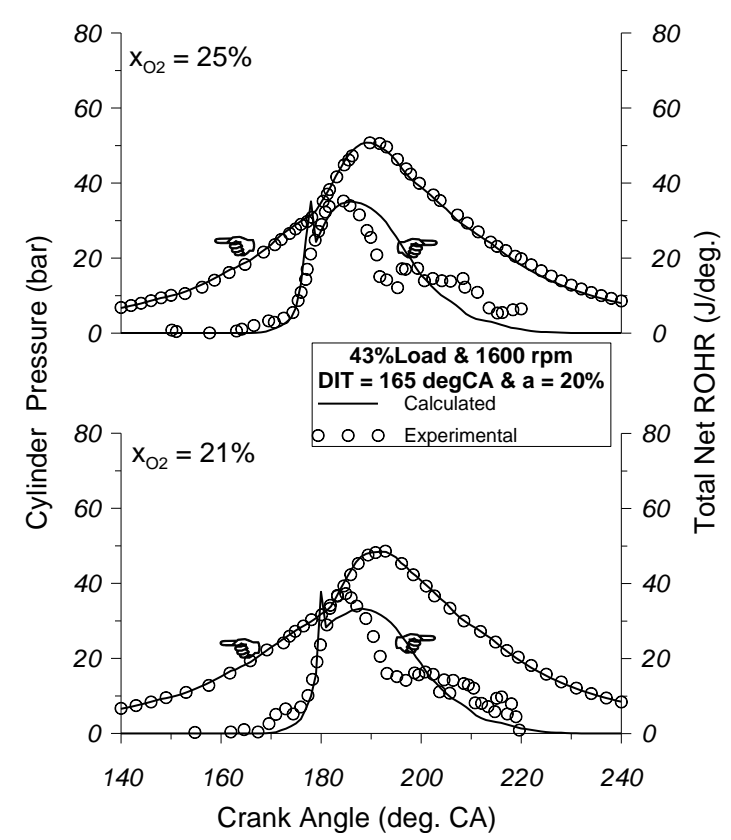

(a)

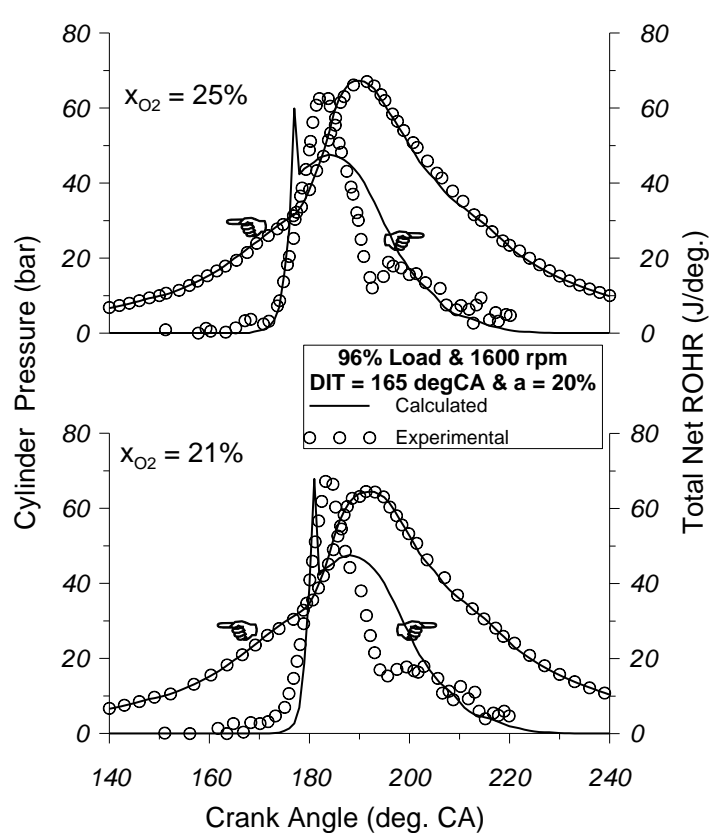

(b)

Figure 2. Comparison between experimental and computed cylinder pressure and total RoHR traces of the test engine for " $\mathrm{x}_{\mathrm{O} 2}$ " $=21 \%$ and $25 \%$ \& "a" $=20 \%$, operating at $43 \%$ of engine rated load \& $1600 \mathrm{rpm}$ engine speed (a); and 96\% of engine rated load \& $1600 \mathrm{rpm}$ engine speed (b).

In Figure 2a, the comparison is provided at part loading conditions (i.e., $43 \%$ of full engine load) and $1600 \mathrm{rpm}$ speed, for three different " $\mathrm{x}_{\mathrm{O} 2}$ " ratios, i.e., $\mathrm{x}_{\mathrm{O} 2}=21 \%, 23 \%$ and $25 \%$, whereas in Figure $2 \mathrm{~b}$ the comparison is given at high loading conditions (i.e., $96 \%$ of full engine load) and $1600 \mathrm{rpm}$ speed for the same " $\mathrm{x}_{\mathrm{O} 2}$ " ratios, i.e., $\mathrm{x}_{\mathrm{O} 2}=21 \%, 23 \%$ and $25 \%$. It must be stated that both experimental and computational rate of heat release (RoHR) diagrams refer to the net total heat release rate. In addition, for all test cases referring to NG/DDF engine operation, the simulation model was calibrated at the high loading point (i.e., $96 \%$ of full load) and $1600 \mathrm{rpm}$ speed, with the intake air charge containing (by vol.) $\mathrm{x}_{\mathrm{O} 2}=21 \%$ oxygen (i.e., "normal air") and for "normal pilot fuel" quantity $(\mathrm{a}=20 \%)$. Comparison of the experimental and theoretical cylinder pressure curves, shown in Figure 2a,b, discloses that the agreement in all test cases presented is relatively good, unveiling the ability of the model in hand to predict sufficiently the engine performance for the specific type of NG/DDF compression ignition engine, operating at various " $\mathrm{x}_{\mathrm{O} 2}$ " ratios, either at part or at high loading conditions. By comparing calculated and measured total rate of heat release traces, a relatively good matching between computed 
and measured diagrams is revealed. A relatively small divergence observed in the second stage of the combustion process could be attributed to the overestimation of the gaseous fuel combustion rate.

Figure 3 assesses the measured and computed results of the brake specific energy consumption (BSEC) corresponding to NG/DDF engine operating mode, for " $\mathrm{x}_{\mathrm{O} 2}$ " $=21 \%, 23 \%$ and $25 \%$ and "normal pilot fuel" quantity, i.e., "a" $=20 \%$, at $\mathrm{N}=1600 \mathrm{rpm}$ speed, for part ( $43 \%$ of full engine load) and high ( $96 \%$ of full load) engine loading conditions, respectively. The experimental BSEC is estimated from the measured brake power, the measured mass flow rates of the diesel fuel and natural gas, and their respective lower heating values. Upon examining Figure 3, a very good match between experimental and computational values of BSEC is revealed. This demonstrates the model's capability to predict the variation trend of the engine performance both with load and with " $\mathrm{x}_{\mathrm{O} 2}$ " ratio.

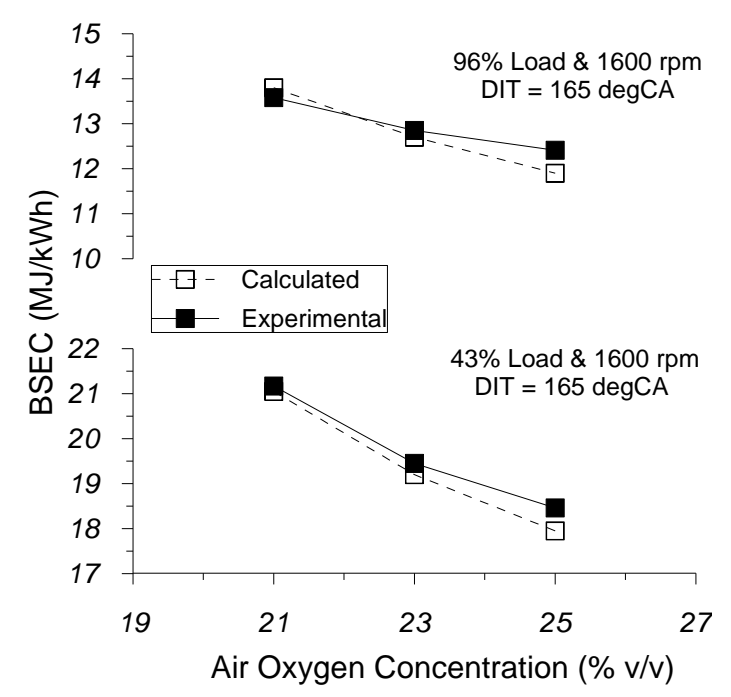

Figure 3. Comparison between experimental and computed BSEC as a function of "inlet-air oxygen ratio", for $\mathrm{N}=1600 \mathrm{rpm}$ and " $\mathrm{a}$ " $=20 \%$, at $43 \%$ and $96 \%$ of engine rated load.

In Figures 4-6 the experimental and computed values of the specific NO, CO and Soot concentrations are compared, corresponding to NG/DDF engine operating mode, for " $\mathrm{x}_{\mathrm{O} 2}$ " $=21 \%$, $23 \%$ and $25 \%$ and "normal pilot fuel" quantity, i.e., $a=20 \%$, at $\mathrm{N}=1600 \mathrm{rpm}$ engine speed, for part ( $43 \%$ of full load) and high ( $96 \%$ of full load) engine loading conditions, respectively. Examining these figures, it is disclosed that the proposed model predicts with sufficient accuracy the variation of specific $\mathrm{NO}$ concentrations with " $\mathrm{x}_{\mathrm{O} 2}$ " ratio. Specifically for the $\mathrm{NO}$ and $\mathrm{CO}$ emissions, the predicted values are slightly lower than the experimental values. This was to be expected from a phenomenological, two-zone combustion model, in which the burning zone temperature, especially during the early stages of the combustion course, is under-predicted. Further, the under-prediction of NO emissions may in part be attributed to that the extended Zeldovich mechanism used in this particular model tracks only nitric oxide (NO) emissions, whereas the experimental results for $\mathrm{NO}_{\mathrm{x}}$ will comprise contributions also from $\mathrm{NO}_{2}$. Finally, the model appears to predict with relatively good precision the measured values of soot emissions and the variation of the measured specific soot concentration with " $\mathrm{x}_{\mathrm{O} 2}$ " ratio. 


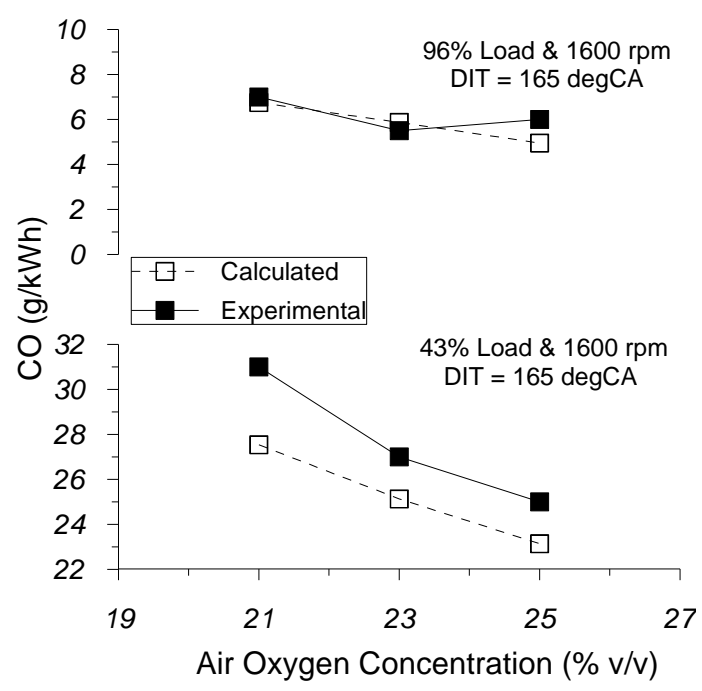

Figure 4. Comparison between experimental and computed specific NO concentration as a function of "inlet-air oxygen ratio", for $\mathrm{N}=1600 \mathrm{rpm}$ and "a" $=20 \%$, at $43 \%$ and $96 \%$ of engine rated load.

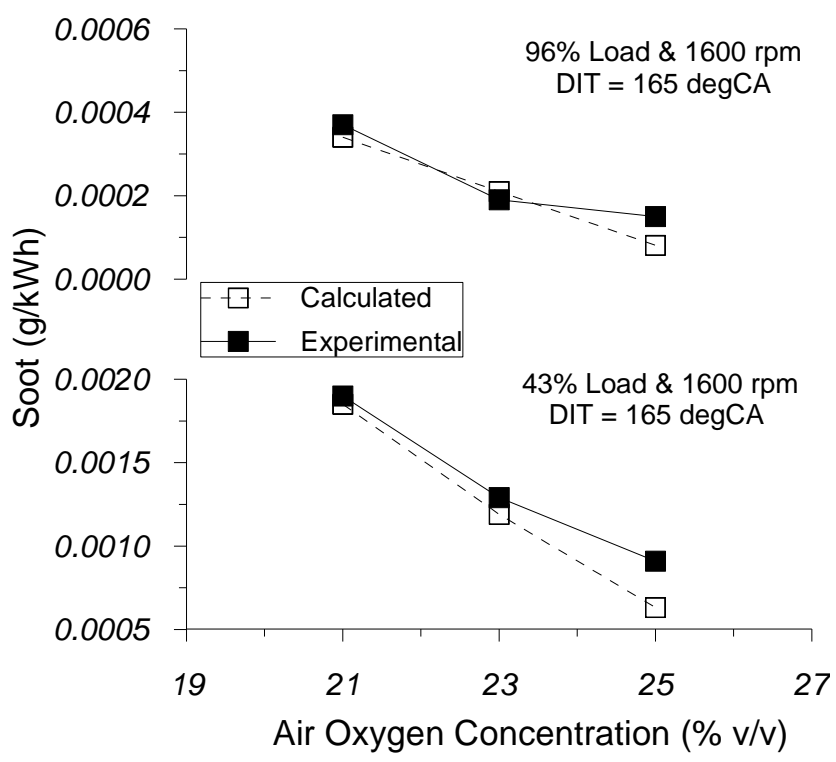

Figure 5. Comparison between experimental and computed specific $\mathrm{CO}$ concentration as a function of "inlet-air oxygen ratio", for $\mathrm{N}=1600 \mathrm{rpm}$ and "a" $=20 \%$, at $43 \%$ and $96 \%$ of engine rated load.

Consequently, the comparison between the experimental and computational results shows that the present model predicts with reasonable accuracy the variation trends of pollutant emissions and performance attributes of the engine, both with the " $\mathrm{x}_{\mathrm{O} 2}$ " ratio and with engine load. Therefore, taking into account the nature of the present study (i.e., comparative assessment), it is confirmed that the specific simulation model can be used to carry out a parametric study regarding the effect of " $\mathrm{x}_{\mathrm{O} 2}$ " ratio in conjunction with the pilot diesel fuel quantity $(\mathrm{a} \%)$, on pollutant emissions and performance attributes of a light-duty, naturally aspirated, direct-injection, NG/DDF engine working at a constant speed of $\mathrm{N}=1600 \mathrm{rpm}$ and two different loading conditions, i.e., $43 \%$ and $96 \%$ of the engine rated load, respectively. 


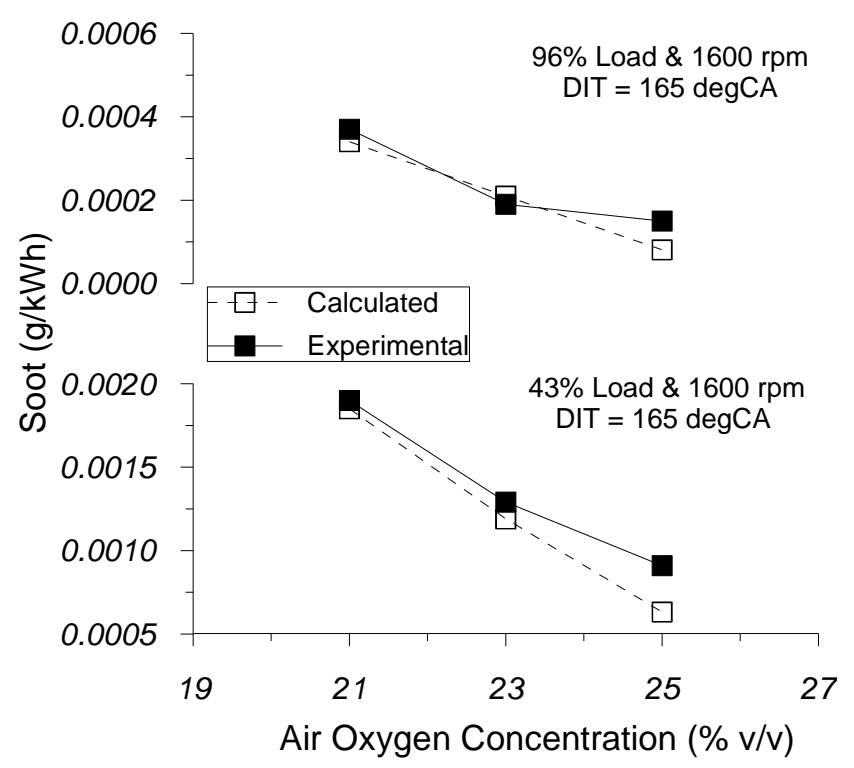

Figure 6. Comparison between experimental and computed specific Soot concentration as a function of "inlet-air oxygen ratio", for $\mathrm{N}=1600 \mathrm{rpm}$ and "a" $=20 \%$, at $43 \%$ and $96 \%$ of engine rated load.

\section{Examined Test Cases}

As mentioned before, in this work efforts are made to predict the relative influence of oxygen concentration of the inducted air in conjunction with the quantity of the pilot diesel fuel, on the performance and emitted pollutants of an existing light-duty, NG/DDF, compression ignition engine, tested at two different engine operating points, i.e., $43 \%$ of full load and $1600 \mathrm{rpm}$, and $96 \%$ of full load and $1600 \mathrm{rpm}$. Thus, for each one of the two above mentioned engine operating points, three different test cases concerning the oxygen concentration of the inducted air were examined (i.e., $x_{\mathrm{O} 2}=21 \%$, $\mathrm{x}_{\mathrm{O} 2}=23 \%$ and $\mathrm{x}_{\mathrm{O} 2}=25 \%$ ). It should be noted that the present study considers also, on top of the above conditions, the cases of pilot diesel fuel quantities of $15 \%$ and $10 \%$ of the rated values, as these are more often encountered in engines of this type. Thus, for every one of the three " $\mathrm{x}_{\mathrm{O} 2}$ " ratios, the pilot diesel fuel quantity, which is expressed as a percentage of the rated value observed under normal diesel engine operating mode ( $\mathrm{a} \%$ ), was decreased from "normal pilot diesel fuel" (i.e., $\mathrm{a}=20 \%$ ) to "a" $=10 \%$ in steps of $5 \%$, i.e., "a" $=20 \%, 15 \%$ and $10 \%$, respectively. Consequently, when the engine works at constant speed (i.e., $1600 \mathrm{rpm}$ ) either at partial (i.e., $43 \%$ of full engine load) or at high (i.e., and $96 \%$ of full engine load) engine load conditions, the following test cases were theoretically examined: "x $\mathrm{O}_{\mathrm{O}}$ " / $" \mathrm{a}$ " = 21\%/20\%; 21\%/15\%; 21\%/10\%; 23\%/20\%; 23\%/15\%; 23\%/10\%; 25\%/20\%; 25\%/15\%; and $25 \% / 10 \%$.

\section{Presentation of Results and their Discussion}

In the present section, the predictive abilities of the phenomenological model in hand are explored. The predicted effects of both parameters examined herein, i.e., the oxygen concentration of the inducted air $\left(\mathrm{x}_{\mathrm{O} 2}\right)$ and the amount of the pilot diesel fuel that is expressed as a percentage of the rated value observed under normal diesel engine operating mode $(\mathrm{a} \%)$, are investigated on some essential performance attributes and pollutant emissions of an existing light-duty, NG/DDF, compression ignition engine, operating at part (i.e., $43 \%$ of full load) and high (i.e., $96 \%$ of full load) engine loading conditions, under constant speed (i.e., $\mathrm{N}=1600 \mathrm{rpm}$ ), respectively.

Figure 7a-c depict the influence of both parameters examined, i.e., " $\mathrm{x}_{\mathrm{O} 2}$ " and "a", on predicted cylinder pressure and heat release rate curves, for $\mathrm{N}=1600 \mathrm{rpm}$ engine speed, at $43 \%$ and $96 \%$ of the engine rated load, respectively. Specifically, in Figure 7a the effect of " $\mathrm{x}_{\mathrm{O} 2}$ " on cylinder pressure and heat release rate diagrams is depicted, for " $\mathrm{a}$ " $=10 \%$ and DIT $=165$ degCA. Examining this figure, it can be seen that for both loads, the increase of " $\mathrm{x}_{\mathrm{O} 2}$ " affects both the cylinder pressure and the heat 
release rate histories. It can be noticed that for the same "a" ratio, throughout the compression stroke, the cylinder pressure corresponding to " $\mathrm{x}_{\mathrm{O} 2}$ " $=21 \%$ deviates from the respective values occurring with increased " $\mathrm{x}_{\mathrm{O} 2}$ " value (i.e., " $\mathrm{x}_{\mathrm{O} 2}$ " $=25 \%$ ). The difference becomes more apparent during the end stages of the compression phase. This could be attributed to the lower specific heat of the natural gas-air mixture. Specifically, according to the main philosophy of the specific model, the inlet air oxygen-enrichment is accompanied by a substitution of some quantity of the intake air mass with pure oxygen, while, at the same time, both diesel and gaseous fuel mass flow rates remain constant.

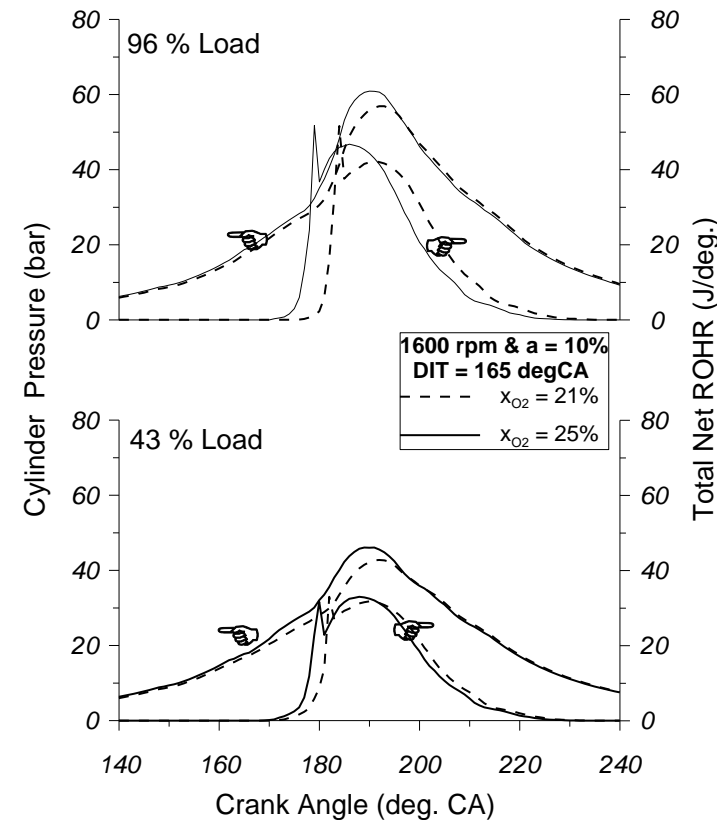

(a)

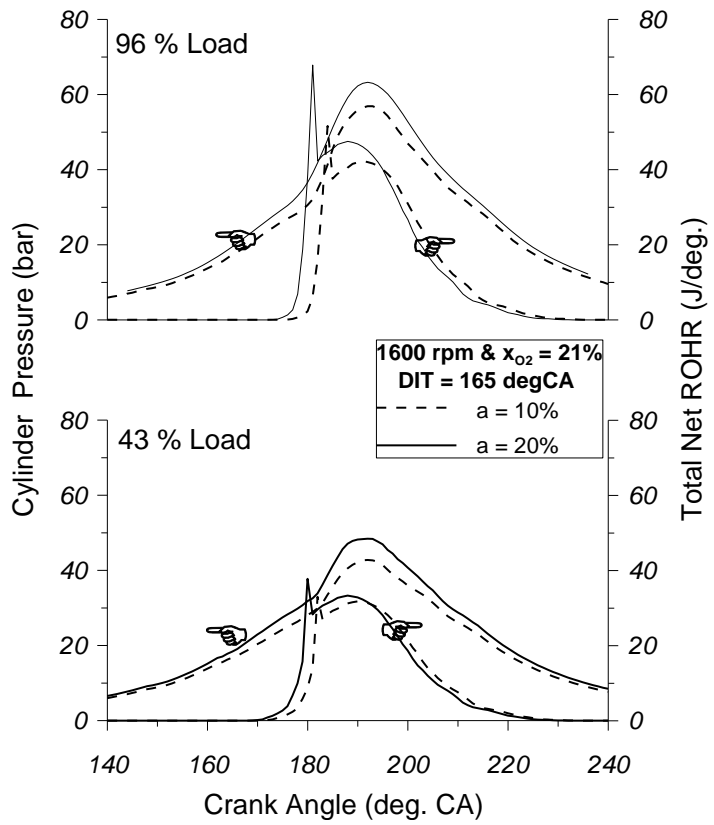

(b)

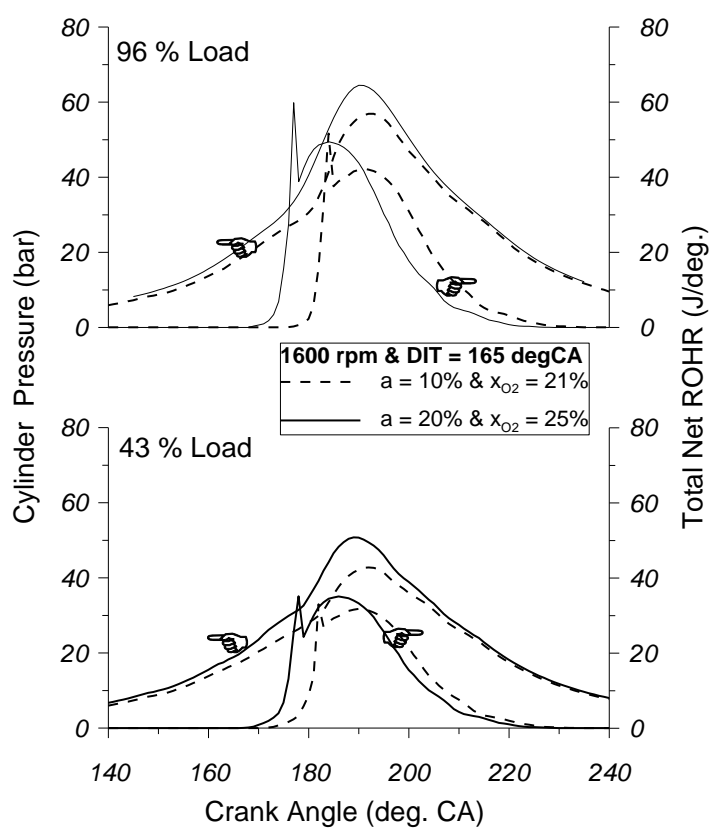

(c)

Figure 7. Calculated cylinder pressure and total RoHR diagrams of test engine operating under $1600 \mathrm{rpm}$ engine speed, at $43 \%$ and $96 \%$ of engine rated load, for " $\mathrm{x}_{\mathrm{O} 2}$ " $=21 \%$ and $25 \%$ \& "a" $=10 \%$ (a); "a" $=10 \%$ and $20 \%$ \& " $x_{\mathrm{O} 2}$ " = 21\% (b); and "a" $=10 \%$ \& " $\mathrm{x}_{\mathrm{O} 2}$ " $=21 \%$ and "a" $=20 \%$ \& " $\mathrm{x}_{\mathrm{O} 2}$ " $=25 \%$ (c). 
As an outcome of this replacement, the oxygen concentration of the cylinder charge is augmented while, at the same time, the nitrogen concentration is mitigated. The higher oxygen concentration of the cylinder charge (i.e., natural gas-air mixture) has a negative effect (decrease) on its specific heat during the compression stroke, a fact that influences positively (slight increase) both the temperature and pressure of the cylinder charge. Moreover, for the same "a" ratio, after the initiation of combustion, the cylinder pressure corresponding to "normal air" (i.e., " $\mathrm{x}_{\mathrm{O} 2}$ " $=21 \%$ ) deviates from the respective values occurring with increased " $\mathrm{x}_{\mathrm{O} 2}$ " ratio, i.e., $\mathrm{x}_{\mathrm{O} 2}=25 \%$. Specifically, it is disclosed that during the first stages of the combustion process, the rate of cylinder pressure rise with increased " $\mathrm{x}_{\mathrm{O} 2}$ " ratio gets higher, while the cylinder pressure peak appears slightly earlier in comparison with the respective values occurring for "normal air".

This could be credited to the earlier start of combustion, which occurred owing to the lower diesel fuel ignition delay period. The earlier initiation of combustion affects positively the rate of heat release, especially during the first stages of the combustion process, since there is an increased fuel mass burned a few crank angle degrees before top dead center (TDC). Regarding the effect of " $\mathrm{x}_{\mathrm{O} 2}$ " ratio on the heat release rate curve, it is disclosed that the increase of " $\mathrm{x}_{\mathrm{O} 2}$ " ratio influences also the combustion rate occurring inside the cylinder. By examining Figure $7 \mathrm{a}$, it is revealed that for equal pilot diesel fuel amount (i.e., "a" $=10 \%$ ) and for both the engine loads under examination herein, the increase of " $\mathrm{x}_{\mathrm{O} 2}$ " ratio does not look to affect much the shape of the heat release rate diagram in comparison with the respective one occurring under "normal air" (i.e., " $\mathrm{x}_{\mathrm{O} 2}$ " $=21 \%$ ) operation mode. However, at the same time, by increasing the " $\mathrm{x}_{\mathrm{O} 2}$ " ratio, combustion initiates earlier since the cylinder charge conditions (pressure and temperature) corresponding to the start of diesel injection point contribute to shorter ignition delay period of the liquid diesel fuel injected. Concurrently, the rate of heat release rise occurring during the first stage of the combustion process gets slightly higher compared to the one occurring at " $\mathrm{x}_{\mathrm{O} 2}$ " $=25 \%$ operation mode. This could be ascribed to the increase of cylinder charge conditions (temperature and pressure), which contribute to the fast spread of the existing flame front enveloping the burning zone. The latter affects positively (augments) the rate of the gaseous fuel combustion.

Figure $7 \mathrm{~b}$ depicts the effect of the "a" ratio on the cylinder pressure and heat release rate diagrams, for "normal air" (i.e., " $\mathrm{x}_{\mathrm{O} 2}$ " $=21 \%$ ) and DIT $=165 \operatorname{degCA}$. Observing this figure, it can be seen that for the same " $\mathrm{x}_{\mathrm{O} 2}$ " ratio and for both engine operating points under examination herein, the increase of the liquid diesel fuel amount influences both the cylinder pressure and the heat release rate histories. It can be noticed that during the compression stroke, the cylinder pressure corresponding to the lower "a" ratio ("a" $=10 \%$ ) deviates from the respective values occurring with increased "a" ratio, i.e., $a=20 \%$. This is experienced for both engine loads. According to the NG/DDF operating principle followed by the particular engine, an increase in liquid diesel fuel quantity is accompanied by a decrease in the mass of the fumigated gaseous fuel (i.e., natural gas). The reduction of the gaseous fuel amount affects negatively (slight decrease) the heat capacity of the cylinder charge (i.e., natural gas-air mixture) at the initiation of the compression phase. The latter factor influences positively (increase) the cylinder charge conditions (temperature and pressure) observed during the compression stroke. Moreover, it is disclosed that during the first stages of the combustion process, the rate of cylinder pressure rise with increased "a" ratio, i.e., "a" $=20 \%$, gets higher, while the cylinder pressure peak occurs a little earlier compared to the respective values occurring for " $a$ " $=10 \%$. This could be owed to the higher combustion rate observed during the first stages of the combustion process, where the combustion heat is chiefly released owing to the premixed controlled combustion rate of the liquid diesel fuel, additionally to the combustion of a tiny part of the gaseous fuel that entrains into the spray.

As concerns the effect of the pilot diesel fuel quantity on the heat release rate curve, it is revealed that for the same " $\mathrm{x}_{\mathrm{O} 2}$ " ratio and for both loads, by increasing the pilot diesel fuel amount the combustion initiates a little earlier, while at the same time the rate of heat released observed during the first stages of the combustion process (i.e., premixed controlled combustion phase) becomes more intense, compared to the one occurring at "a" $=10 \%$ operation mode. Thus, the respective peak value 
of the heat released is increased as well. The earlier initiation of combustion could be attributed to the lower diesel fuel ignition delay period, since the increase of the pilot diesel fuel amount results in a slight increase of the cylinder charge temperature existing at the initiation of diesel fuel injection process. On the other hand, the increased values of heat released observed for the period of the premixed controlled combustion phase, could be attributed both to the enhanced evaporation rate of the injected liquid diesel fuel and also to the increased gaseous fuel-air mixture entrainment rate into the burning zone. The latter factor promotes the flame spread through the premixed gaseous fuel-air mixture charge, thus leading to higher peak heat released values.

Figure $7 \mathrm{c}$ depicts the combined effect of both parameters under examination here (i.e., " $\mathrm{x}_{\mathrm{O} 2}$ " and "a" ratios) on cylinder pressure and heat release rate diagrams, for DIT $=165 \operatorname{degCA}$, at $43 \%$ and $96 \%$ of the rated load and $1600 \mathrm{rpm}$ speed. Observing this figure, it can be noticed that the increase of " $\mathrm{x}_{\mathrm{O} 2}$ " ratio accompanied by an increase of the pilot diesel fuel amount, directs to a more sharp increase of the cylinder pressure, especially over the last stages of the compression stroke and the first stages of the combustion process. At the same time, the simultaneous increase of both parameters seems to result in an earlier occurrence of the maximum cylinder pressure in comparison to the respective values occurring under " $\mathrm{x}_{\mathrm{O} 2}$ " $=21 \%$ and " $\mathrm{a}$ " $=10 \%$ operating modes. Furthermore, as regards the combined effect of both parameters on heat release rate diagram, it is disclosed that the concurrent increase of both parameters guides to an earlier initiation of combustion and also to a more intense combustion rate that becomes more evident during the initial stage of the combustion process, where the combustion heat is primarily released owing to the premixed controlled combustion rate of the liquid diesel fuel.

Figure 8 illustrates the variation of the computed duration of combustion $(\mathrm{DoC})$ versus the " $\mathrm{x}_{\mathrm{O} 2}$ " ratio, for "a" $=10 \%, 15 \%$ and $20 \%$. All predictions are given at $43 \%$ and $96 \%$ of full engine load, for $1600 \mathrm{rpm}$ speed and constant diesel injection timing DIT $=165 \mathrm{degCA}$. By probing this figure, it is observed that both parameters examined herein affect the DoC. Specifically, for both loads, the increase of " $\mathrm{x}_{\mathrm{O} 2}$ " ratio, under constant " $\mathrm{a}$ " ratio, leads to a decrease of the DoC. This particular effect is ascribed primarily to that the increase of " $\mathrm{x}_{\mathrm{O} 2}$ " ratio leads to a small earlier initiation of combustion and also to an improvement of the gaseous fuel combustion. The latter one is attributed mainly to the fact that the increased oxygen concentration supports the flame propagation mechanism, which promotes the gaseous fuel combustion rate. As concerns the effect of the "a" ratio on DoC, it is disclosed that for both loads the increase of "a" ratio, for the same air oxygen concentration, seems to shorten slightly the DoC. This may be primarily owed to the slight improvement of the liquid fuel combustion quality, especially during the first stage of the combustion process, where the combustion heat is chiefly released owing to the premixed controlled combustion rate of the liquid diesel fuel.

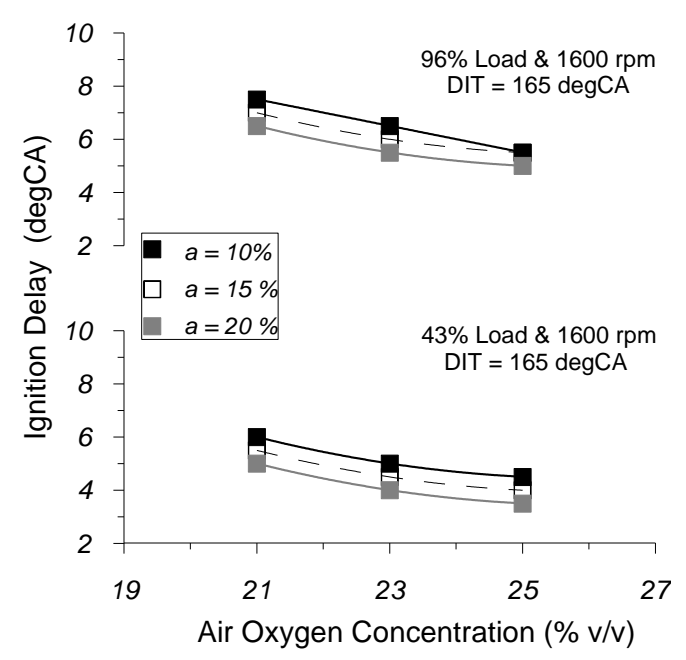

Figure 8. Calculated DoC versus "inlet-air oxygen ratio" for various "diesel fuel quantity ratios", at $43 \%$ and $96 \%$ of engine rated load and $1600 \mathrm{rpm}$ engine speed, for DIT = $165 \mathrm{degCA}$. 
Figure 9 depicts the variation of ignition delay period against " $\mathrm{x}_{\mathrm{O} 2}$ " ratio, for three different " $\mathrm{a}$ " ratios, i.e., $\mathrm{a}=10 \%, 15 \%$ and $20 \%$, at part (i.e., $43 \%$ of full load) and high (i.e., $96 \%$ of full load) load conditions, for $1600 \mathrm{rpm}$ speed and constant diesel injection timing DIT $=165 \mathrm{degCA}$.

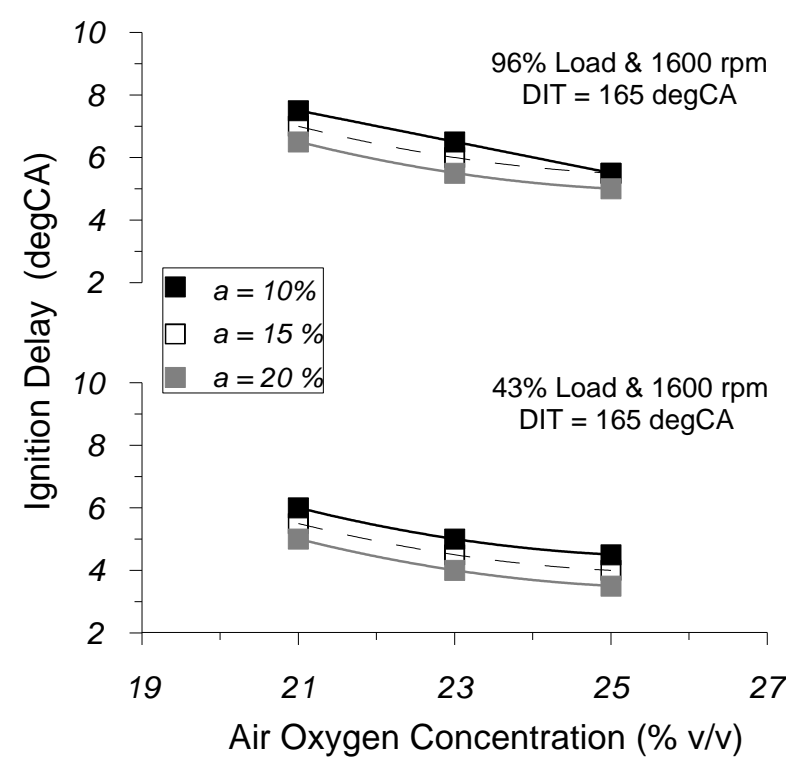

Figure 9. Calculated Ignition delay period versus "inlet-air oxygen ratio" for various "diesel fuel quantity ratios", at $43 \%$ and $96 \%$ of engine rated load and $1600 \mathrm{rpm}$ engine speed, for DIT = $165 \mathrm{degCA}$.

It should be mentioned here that the ignition delay period is defined as the time period from the start of diesel fuel injection to the commencement of combustion. The period of ignition delay is predominantly controlled by the conditions (i.e., pressure, temperature, total air excess ratio) of the cylinder charge at the start of the diesel fuel injection. By examining Figure 9, it is disclosed that for both engine operating points and for equal " $\mathrm{x}_{\mathrm{O} 2}$ " ratio, the increase of "a" ratio guides to a slight reduction of the ignition delay period. As already mentioned above, the increase of pilot diesel fuel mass leads to a small increase of the cylinder charge temperature that occurs inside the liquid fuel spray during the ignition delay period, a fact that contributes sensibly to the improvement of both evaporation and entraintment rates. What is more, for equal pilot diesel fuel quantity, the increase of " $\mathrm{x}_{\mathrm{O} 2}$ " ratio leads to a more sensible drop of the ignition delay period. This may be primarily ascribed to that the ignition delay period is inversely proportional to the pressure in the cylinder as well as to the temperature in the burning zone. Thus, by increasing the " $\mathrm{x}_{\mathrm{O} 2}$ " ratio, the cylinder charge conditions (i.e., temperature and pressure) that exist inside the cylinder during the initiation of injection get higher, thus leading to a decrease of the ignition delay period. Further, the increase of " $\mathrm{x}_{\mathrm{O} 2}$ " ratio leads to a decrease of the mixture total equivalence ratio in the burning zone, which also influences positively (i.e., decrease) the period of ignition delay.

The investigation of the effect of " $\mathrm{x}_{\mathrm{O} 2}$ " and "a" ratios on the maximum cylinder pressure is of utmost interest, since this engine performance attribute is a crucial parameter affecting the engine-structure mechanical strength. Thus, at part (i.e., $43 \%$ of full load) and high (i.e., $96 \%$ of full load) engine loading conditions and $1600 \mathrm{rpm}$ speed, the variation of the predicted peak cylinder pressure with " $\mathrm{x}_{\mathrm{O} 2}$ " and "a" ratios, for constant diesel injection timing, i.e., $\mathrm{DIT}=165 \mathrm{degCA}$, is given in Figure 10. By examining this figure, it is disclosed that for both engine loading points, the increase of pilot diesel fuel quantity, by keeping equal the " $\mathrm{x}_{\mathrm{O} 2}$ " ratio, results in a small increase of the peak cylinder pressure. As already mentioned above, this may be owed to the enhancement of the liquid diesel fuel combustion rate, in particular during the first stages of the combustion process. On the other hand, it is seen that the increase of " $\mathrm{x}_{\mathrm{O} 2}$ " ratio with constant " $\mathrm{a}$ " ratio leads also to a more sensible rise of the peak cylinder pressure. This is mainly ascribed to that the increase of " $\mathrm{x}_{\mathrm{O} 2}$ " ratio, in comparison to the effect of "a" ratio, affects more intensely the gaseous fuel combustion quality, mainly 
over the premixed controlled combustion phase. The increased oxygen concentration accelerates the propagation rate of the flame front, a fact that enhances the combustion rate of the gaseous fuel, hence leading to an increased amount of the gaseous fuel burned before TDC. The latter one influences positively the rate of increase of the peak cylinder pressure.

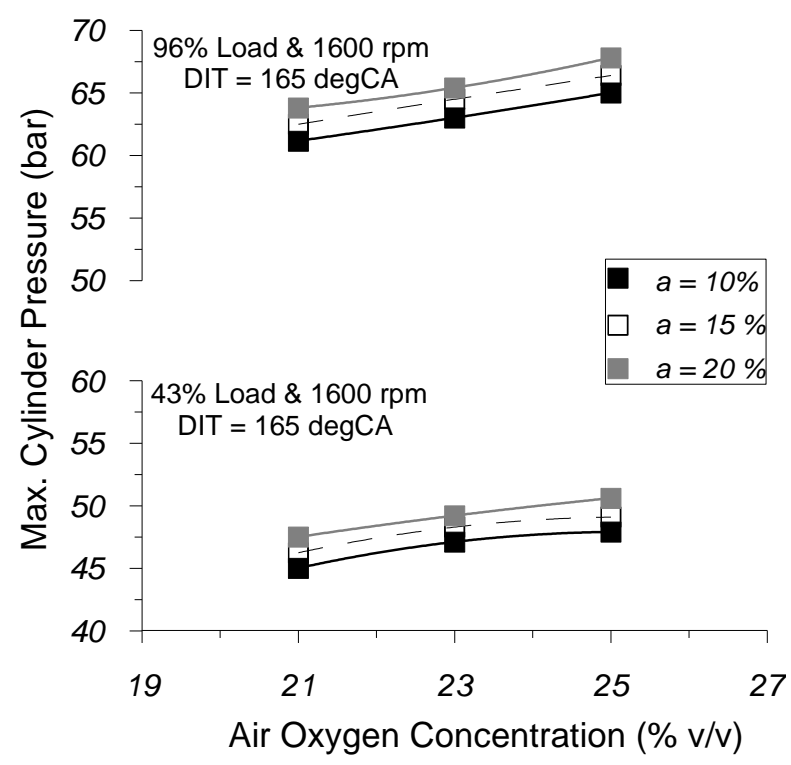

Figure 10. Calculated maximum cylinder pressure versus "inlet-air oxygen ratio" for various "diesel fuel quantity ratios", at $43 \%$ and $96 \%$ of engine rated load and $1600 \mathrm{rpm}$ engine speed, for DIT $=165$ degCA.

By comparing the results shown in Figure 10, it is observed that at high load the concurrent increase of both parameters could lead to a sensible rise of the maximum cylinder pressure, a fact that could cause serious problems with regard to the mechanical strength of the engine structure. Besides, at part load, an improvement of engine performance characteristics seems to be more possible to be achieved through the simultaneous increase of both parameters without inflicting major problems to the engine mechanical strength, since the rise of the peak cylinder pressure seems to be restricted

Figure 11 shows the variation of brake specific energy consumption (BSEC) against " $\mathrm{x}_{\mathrm{O} 2}$ " ratio, for three different "a" values, i.e., a $=10 \%, 15 \%$ and $20 \%$. All predictions are given at $43 \%$ and $96 \%$ of full engine load, for $1600 \mathrm{rpm}$ engine speed and constant diesel injection timing DIT $=165 \mathrm{degCA}$. It must be stated here that the BSEC was estimated from the computed brake power, the computed mass flow rates of diesel fuel and natural gas, and their respective lower heating values. The brake power was computed by the simulation model using the predicted brake mean effective pressure, as derived from the integration of the predicted cylinder pressure trace and the mechanical efficiency of engine. 


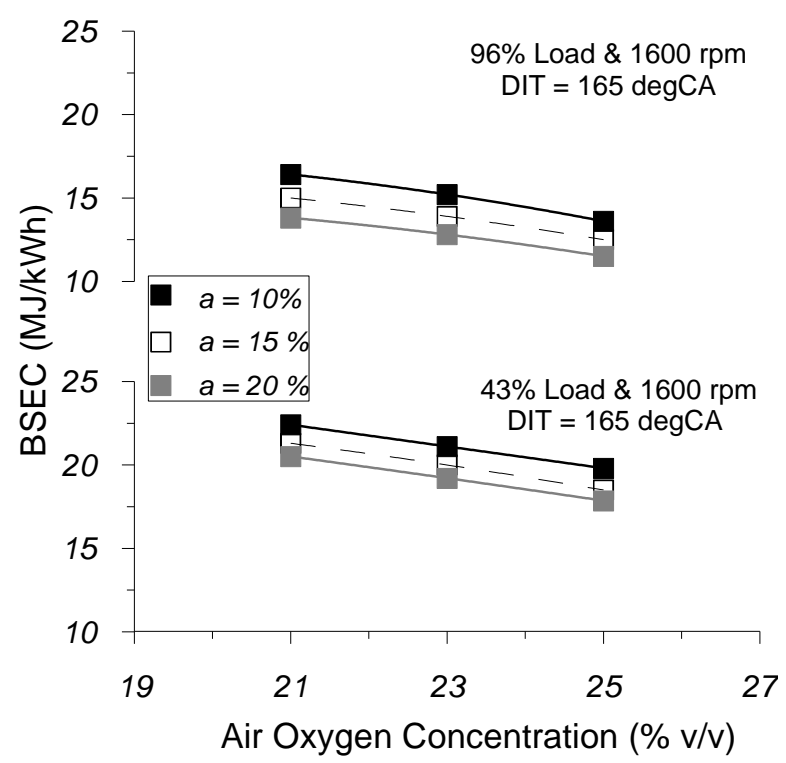

Figure 11. Calculated brake specific energy consumption versus "inlet-air oxygen ratio" for various "diesel fuel quantity ratios", at $43 \%$ and $96 \%$ of engine rated load and $1600 \mathrm{rpm}$ engine speed, for DIT $=165$ degCA.

Observing Figure 11, it is disclosed that every one of the examined parameters here affects positively (improves) the engine brake thermal efficiency. Specifically, it is seen that for both loads the increase of "a" ratio, keeping equal " $\mathrm{x}_{\mathrm{O} 2}$ " ratio, leads to an improvement (decrease) of the BSEC. This may be due to the improvement of the liquid diesel fuel premixed controlled combustion quality, since the duration of combustion gets slightly shorter and more of the liquid diesel fuel is combusted close to TDC. Moreover, it is seen that for both loads, the increase of " $\mathrm{x}_{\mathrm{O} 2}$ " ratio leads also to an improvement (decrease) of BSEC. The increase of air oxygen concentration, holding constant the pilot diesel fuel quantity, results in a shorter liquid diesel fuel ignition delay period, which when combined with the elevated cylinder charge temperature plays a positive role (promote) on the flame propagation process, thus adding also to the enhancement of the gaseous fuel combustion quality. The latter one leads to a shorter DoC period and also to higher amount of gaseous fuel combusted before TDC. Finally, as evidenced by observing the same figure, BSEC seems to be more sensitive to the variation of " $\mathrm{x}_{\mathrm{O} 2}$ " ratio as compared to the corresponding influence of "a" ratio. Therefore, the increased " $\mathrm{x}_{\mathrm{O} 2}$ " ratio in conjunction with increased "a" ratio appears to contribute to a sensible improvement of the engine efficiency.

Figure 12 provides the variation of the computed specific $\mathrm{NO}$ concentration $(\mathrm{spNO})$ versus " $\mathrm{x}_{\mathrm{O} 2}$ " ratio. The results refer to $43 \%$ and $96 \%$ of full load, for a $=10 \%, 15 \%$ and $20 \%$ operation modes, at $1600 \mathrm{rpm}$ speed. Observing this figure, it is disclosed that for every combination of " $\mathrm{x}_{\mathrm{O} 2}$ " and " $\mathrm{a}$ " ratios, the increase in engine loading conditions guides to a more or less insignificant variation of the computed specific NO emissions. As known, the raise of engine load results in an augmentation of the brake power. However, at the same time, the increase of engine load is escorted by an increase of the peak burning zone temperature, a fact that enforces the NO formation mechanism. Regarding the effect of " $\mathrm{x}_{\mathrm{O} 2}$ " ratio on the calculated spNO emissions, it is revealed that for both engine loads and for every one of the three " $a$ " ratios examined, the increase in the air oxygen concentration leads to an increase of the computed spNO emissions. As known [21,22,57], the mechanism of NO formation is primarily controlled by the cylinder charge temperature and less by the availability of the local oxygen. The increase of " $\mathrm{x}_{\mathrm{O} 2}$ " ratio causes an earlier initiation of combustion relative to TDC, which affects positively (increase) the temperature in the burning zone and moreover it results in elevated oxygen availability inside the burning zone. Both these factors enhance the NO formation mechanism, revealing thus the increase of specific $\mathrm{NO}$ emissions. 


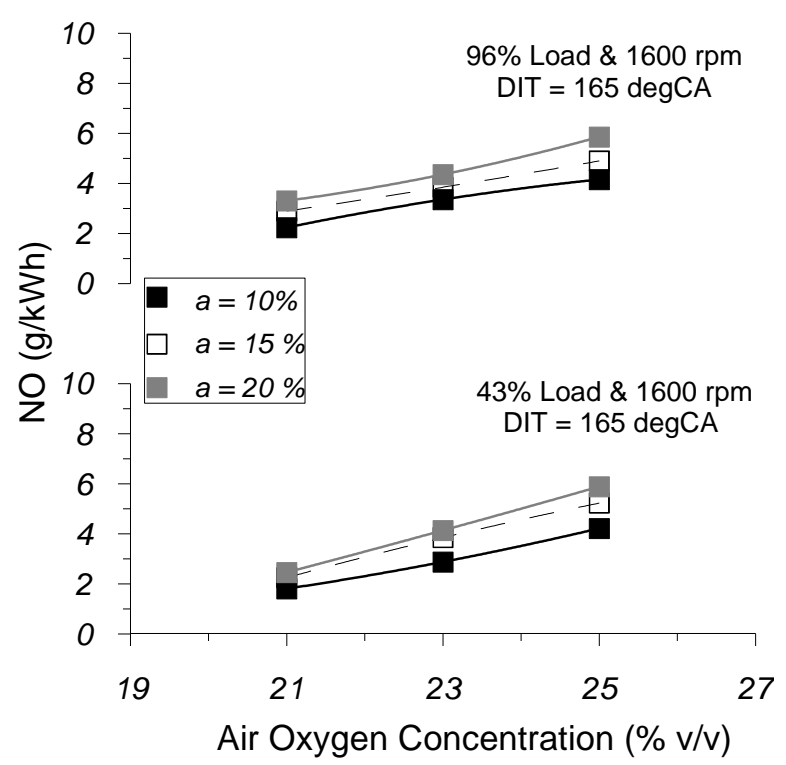

Figure 12. Calculated specific NO concentration versus "inlet-air oxygen ratio" for various "diesel fuel quantity ratios", at $43 \%$ and $96 \%$ of engine rated load and $1600 \mathrm{rpm}$ engine speed, for DIT = $165 \mathrm{degCA}$.

As concerns the effect of the "a" ratio on the spNO concentration, it is disclosed that for both loads and for equal " $\mathrm{x}_{\mathrm{O} 2}$ " ratio, the increase of pilot diesel fuel mass leads to a slight increase of the calculated spNO. This effect seems to be more intense at higher " $\mathrm{x}_{\mathrm{O} 2}$ " ratios. This is attributed to that the increase of "a" ratio results in an augmentation of the heat released over the initial stage of the combustion process, where the combustion heat is mainly released owing to the rate of premixed controlled combustion of the liquid diesel fuel. It results to an increase of the burning zone temperature, promoting thus the NO formation mechanism. Finally, the two strategies examined here promote the NO formation mechanism. By comparing the respective results given in Figure 12, it is disclosed that spNO emissions look to be more sensitive to the increase of " $\mathrm{x}_{\mathrm{O} 2}$ " ratio than to the increase of pilot fuel quantity. This is mainly attributed to that the first strategy (increase in " $\mathrm{x}_{\mathrm{O} 2}$ " ratio) affects both the oxygen availability and the temperature inside the burning zone.

Figure 13 gives the variation of the computed specific $\mathrm{CO}$ concentration $(\mathrm{spCO})$ versus " $\mathrm{x}_{\mathrm{O} 2}$ " ratio. The results refer to $43 \%$ and $96 \%$ of full load, for $\mathrm{a}=10 \%, 15 \%$ and $20 \%$ operation modes, at 1600 rpm speed. As known [21,22,57], the rate of $\mathrm{CO}$ formation is dependent on the air to fuel excess ratio, the availability of the unburned gaseous fuel, and the temperature of the cylinder charge. The latter parameter favors the $\mathrm{CO}$ oxidation rate. Regarding the effect of engine load on the spCO concentration, it is seen that for every combination of " $\mathrm{x}_{\mathrm{O} 2}$ " and " $\mathrm{a}$ " ratios, the increase in engine load leads to a decrease of the calculated spCO. As stated before, the increase of engine load guides to an increase of the brake power. However, concurrently, it is escorted by an increase of the peak burning zone temperature, an issue that favors the $\mathrm{CO}$ oxidation mechanism. By examining the same figure, it is noticed that for the two loads in hand, the increase of "a" ratio, keeping constant the air oxygen concentration, leads to a slight drop of the spCO emissions. This is ascribed to the augmentation of the rate of the liquid diesel fuel combustion, in particular over the first stages of the combustion process, which increases the burning zone temperature, hence promoting the $\mathrm{CO}$ oxidation rate. 


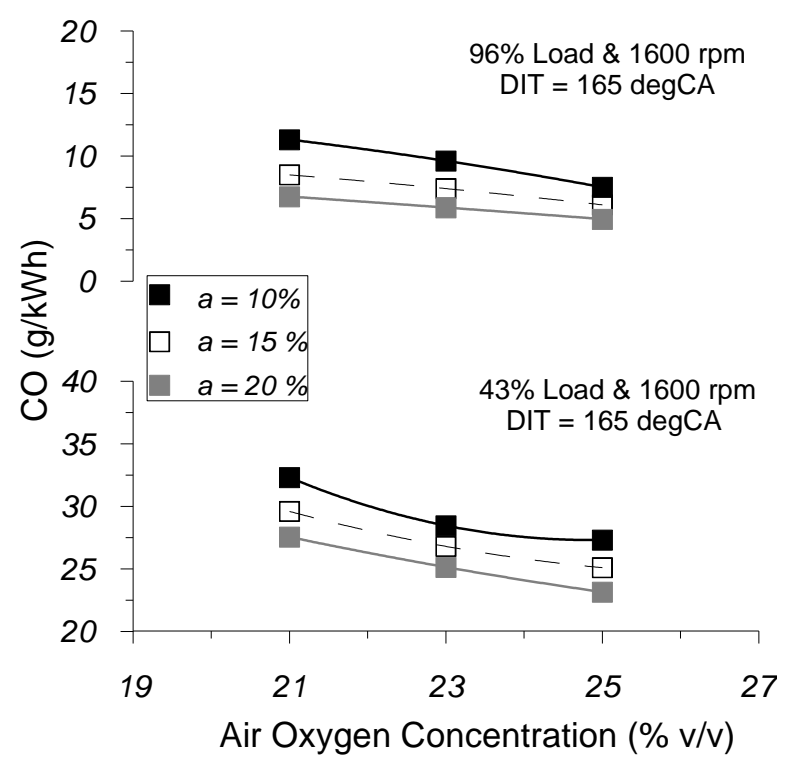

Figure 13. Calculated specific CO concentration versus "inlet-air oxygen ratio" for various "diesel fuel quantity ratios", at $43 \%$ and $96 \%$ of engine rated load and $1600 \mathrm{rpm}$ engine speed, for DIT = $165 \mathrm{degCA}$.

As regards the effect of " $\mathrm{x}_{\mathrm{O} 2}$ " ratio on the $\mathrm{spCO}$ emissions, it is disclosed that the increase of " $\mathrm{x}_{\mathrm{O} 2}$ " ratio affects also positively (decrease) the spCO emissions. The increase of " $\mathrm{x}_{\mathrm{O} 2}$ " ratio causes an earlier commencement of combustion relative to TDC. This results to an elevation of the peak cylinder temperature, a factor that promotes the $\mathrm{CO}$ formation mechanism. At the same time, this particular strategy affects positively (promotes) the $\mathrm{CO}$ oxidation rate, since it permits for more mass of the $\mathrm{CO}$ formed to be entirely oxidized. Consequently, the increase of " $\mathrm{x}_{\mathrm{O} 2}$ " ratio results in a drop of the indicated spCO concentrations. Finally, by examining Figure 13, it is disclosed that the effect of " $\mathrm{x}_{\mathrm{O} 2}$ " ratio on spCO emissions looks to be more severe, in comparison to the respective effect that is caused by the variation of the pilot diesel fuel quantity. Therefore, the increase of " $\mathrm{x}_{\mathrm{O} 2}$ " ratio in combination with increased "a" ratio may lead to improved spCO emissions.

The variation of the specific soot concentration (spSoot) with " $\mathrm{x}_{\mathrm{O} 2}$ " ratio for various "a" ratios, at $43 \%$ and $96 \%$ of the rated load and $1600 \mathrm{rpm}$ engine speed, is shown in Figure 14. Concerning the effect of engine load on spSoot concentration, it is seen that for every combination of " $\mathrm{x}_{\mathrm{O} 2}$ " and "a" ratios, the increase in engine load leads to a considerable decrease of the computed specific soot concentrations. As stated before, the increase of engine load guides to an increase of the brake power. Simultaneously, it is escorted by an elevation of the peak burning zone temperature, an issue that favors the soot oxidation mechanism. By examining Figure 14, it is observed that for the loads in hand the increase of "a" ratio, keeping constant " $\mathrm{x}_{\mathrm{O} 2}$ " ratio, leads to a small drop of the spSoot emissions. This is mainly owed to that as the diesel fuel quantity increases, the rate of the premixed controlled combustion of the liquid diesel fuel increases too. This results in more elevated burning zone temperature, in particular over the first stages of the combustion process, which eventually enhances the soot oxidation mechanism, hence leading to the decrease of the emitted specific soot concentrations. 


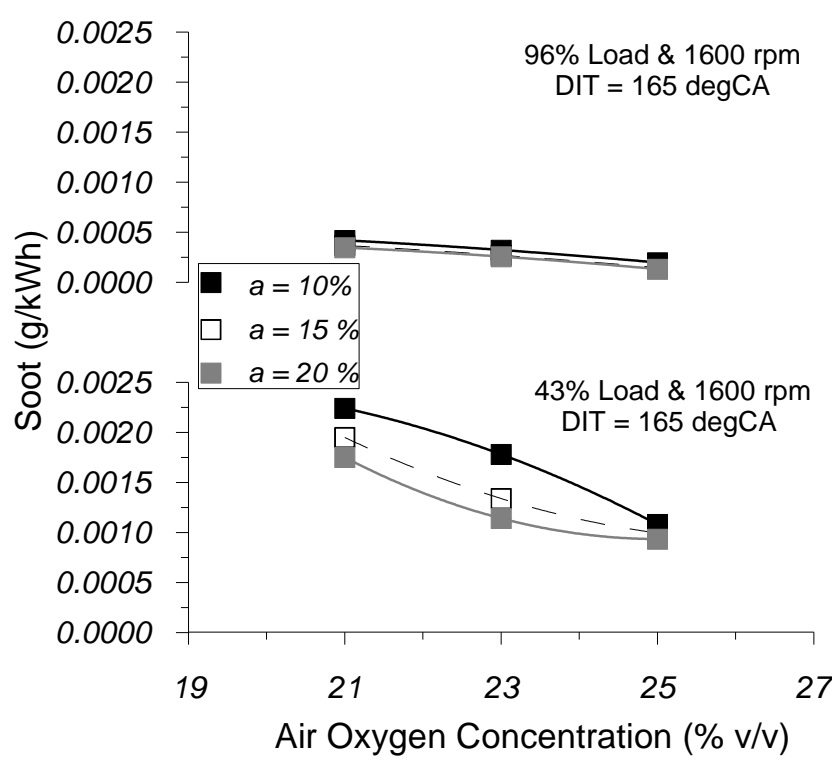

Figure 14. Calculated specific Soot concentration versus "inlet-air oxygen ratio" for various "diesel fuel quantity ratios", at 43\% and 96\% of engine rated load and $1600 \mathrm{rpm}$ engine speed, for DIT = 165 degCA.

As regards the effect of " $\mathrm{x}_{\mathrm{O} 2}$ " ratio on the specific soot emissions, it is disclosed that the increase of " $\mathrm{x}_{\mathrm{O} 2}$ " ratio affects also positively (decrease) the specific soot emissions. This is due to that the increase in " $\mathrm{x}_{\mathrm{O} 2}$ " ratio leads to an enhancement of the rate of the gaseous fuel combustion, which has as a result the higher cylinder peak temperatures. The increased burning zone temperature not only favors the soot oxidation mechanism, but also it restrains the soot formation rate, hence adding on to the considerable reduction of the specific soot concentrations. Moreover, the increase of " $\mathrm{x}_{\mathrm{O} 2}$ " ratio leads to an earlier, relative to TDC position, initiation of combustion, which is a factor restraining the soot formation mechanism, thus contributing to a further decrease of the emitted specific soot concentrations. Finally, by examining the results depicted in Figure 14, it is observed that the increment of " $\mathrm{x}_{\mathrm{O} 2}$ " ratio seems to affect more intensely the specific soot concentrations, in comparison to the respective effect that is caused by the pilot diesel fuel quantity increase.

\section{Summary and Conclusions}

An in-house, two-zone of combustion, phenomenological model is used in this study to investigate the combined effects of two crucial engine parameters, i.e., the inlet-air oxygen concentration ratio and the diesel fuel quantity ratio, on the performance attributes and exhaust emissions of a light-duty, naturally aspirated, NG/DDF, compression ignition engine, operating under constant speed (1600 rpm), either at part (i.e., $43 \%$ of full load) or high (i.e., $96 \%$ of full load) engine loading conditions, for constant pilot diesel fuel injection timing (DIT $=165$ degCA), respectively.

To verify the predictive capability of the model in hand, experimental data were taken from an extended pertinent experimental investigation. By comparing the computed and measured cylinder pressure and total rate of heat release histories, a good matching between computed and measured diagrams is revealed. Furthermore, by comparing the computed and measured values of the maximum cylinder pressure, brake specific energy consumption, specific NO, CO and Soot emissions, a very good coincidence is evidenced for all engine operating modes examined.

By assessing the findings derived from the application of the model, the most important conclusions may be summarized as follows:

For constant inlet-air oxygen concentration ratio, the increase of the diesel fuel quantity ratio guides to a rise of the heat released over the first part of the combustion process. This could be escorted by a small decrease of the duration of combustion, a fact that seems to have a positive influence (tiny decrease) on the brake specific energy consumption. Simultaneously, the increase of the diesel fuel 
quantity ratio guides to an increase of the peak cylinder pressure. As regards the effect of diesel fuel quantity ratio on the specific $\mathrm{NO}, \mathrm{CO}$ and soot concentrations, the increase of diesel fuel quantity ratio appears to promote the NO formation mechanism, thus resulting to higher NO concentrations, while, at the same time, it leads to lower concentrations of both $\mathrm{CO}$ and soot emissions.

For constant diesel fuel quantity ratio, the increase of inlet-air oxygen concentration ratio leads to shorter liquid fuel ignition delay periods, which is accompanied by an amelioration of the combustion quality of gaseous fuel. The enhancement of the gaseous fuel combustion quality directs to shorter length of the combustion period, a fact that seems to result in a sensible improvement of the BSEC. However, the increase of inlet-air oxygen concentration ratio appears to lead to higher levels of peak cylinder pressure. As concerns the effect of inlet-air oxygen concentration ratio on the specific NO, $\mathrm{CO}$ and soot concentrations, it is disclosed that the increase of inlet-air oxygen concentration ratio accelerates the commencement of combustion, which impacts negatively (increases) on the specific NO emissions. Nonetheless, this particular methodology seems to have a positive influence (reduce) on both $\mathrm{CO}$ and Soot emissions. Specifically, by increasing the inlet-air oxygen concentration ratio the specific $\mathrm{CO}$ concentrations become lower, while the specific Soot emissions seem also to be curtailed.

Generally speaking, the variation of inlet-air oxygen concentration ratio in combination with the variation of diesel fuel quantity ratio may be a solution worth looking at, in order to improve the performance characteristics with a simultaneous reduction of $\mathrm{CO}$ emissions, for an existing compression ignition engine operating under NG/DDF mode at part load conditions. If the engine operates at high loading conditions, then particular attention should be paid to the fact that the concurrent rising of both parameters could be practically appropriate if it was accompanied by a simultaneous retardation of pilot diesel injection timing. This is because, for retarded diesel fuel injection timings, the peak cylinder pressure does not seem to surpass much the values of the peak cylinder pressure encountered under normal diesel fuel injection timing (i.e., DIT $=165 \operatorname{degCA}$ ), as well. Concerning the use of oxygen enrichment, it is mentioned that the use of separation membranes is a known methodology for non-cryogenic separation of oxygen from the atmospheric air. This technology is not an economical solution yet, but continuous developments in membrane separation techniques may render this option economically viable in the future, and this is why this technique is worth investigating for.

Author Contributions: R.G.P.: Formal Analysis. D.C.R.: Methodology. C.D.R.: Project administration.

Funding: This research received no external funding.

Conflicts of Interest: The authors declare no conflict of interest.

\section{Nomenclature}

$\begin{array}{ll}\text { Abbreviations } & \\ \text { a } & \text { Diesel fuel quantity ratio (\%) } \\ \text { AFR } & \text { Air to fuel ratio (by mass) } \\ \text { BDC } & \text { Bottom dead center } \\ \text { BSEC } & \text { Brake specific energy consumption } \\ \text { CA } & \text { Crank angle } \\ \text { CI } & \text { Compression ignition } \\ \text { CNG } & \text { Compressed natural gas } \\ \text { CO } & \text { Carbon monoxide } \\ \text { DDF } & \text { Diesel dual-fuel } \\ \text { DI } & \text { Direct injection } \\ \text { DIT } & \text { Diesel fuel injection timing } \\ \text { DoC } & \text { Duration of combustion }\end{array}$




$\begin{array}{ll}\mathrm{HC} & \text { Unburned hydrocarbons } \\ \mathrm{NDO} & \text { Normal diesel engine operating mode } \\ \mathrm{NG} & \text { Natural gas } \\ \mathrm{NO} & \text { Nitric oxide } \\ \mathrm{NO}_{2} & \text { Nitrogen dioxide } \\ \mathrm{NOx} & \text { Nitrogen oxides } \\ \mathrm{PM} & \text { Particulate matter } \\ \mathrm{RoHR} & \text { Rate of heat release } \\ \mathrm{SEC} & \text { Specific energy consumption } \\ \mathrm{sp} & \text { Specific (emissions) } \\ \mathrm{TDC} & \text { Top dead center } \\ \mathrm{x}_{\mathrm{O} 2} & \text { Inlet-air oxygen ratio (\%) }\end{array}$

\section{References}

1. Rakopoulos, C.D.; Giakoumis, E.G. Diesel Engine Transient Operation-Principles of Operation and Simulation Analysis; Springer: London, UK, 2009.

2. Rakopoulos, C.D.; Giakoumis, E.G.; Hountalas, D.T.; Rakopoulos, D.C. The Effect of Various Dynamic, Thermodynamic and Design Parameters on the Performance of a Turbocharged Diesel Engine Operating under Transient Load Conditions; SAE Technical Paper 2004-01-0926; SAE International: New York, NY, USA, 2004.

3. Merola, S.S.; Irimescu, A.; Marchitto, L.; Tornatore, C.; Valentino, G. Effect of injection timing on combustion and soot formation in a direct injection spark ignition engine fueled with butanol. Int. J. Engine Res. 2017, 18, 490-504. [CrossRef]

4. Rakopoulos, C.D.; Mavropoulos, G.C. Experimental instantaneous heat fluxes in the cylinder head and exhaust manifold of an air-cooled diesel engine. Energy Convers. Manag. 2000, 41, 1265-1281. [CrossRef]

5. Levendis, Y.A.; Panagiotou, T.; Tasilm, M.E. Development of a Self-Cleaning Particle Trap for Diesel Engine Particulate Control; SAE Technical Paper 900601; SAE International: New York, NY, USA, 1990.

6. Rakopoulos, C.D.; Rakopoulos, D.C.; Mavropoulos, G.C.; Giakoumis, E.G. Experimental and theoretical study of the short term response temperature transients in the cylinder walls of a diesel engine at various operating conditions. Appl. Therm. Eng. 2004, 24, 679-702. [CrossRef]

7. Agathou, M.S.; Kyritsis, D.C. Experimental study of steady, quasi cone-jet electrostatic sprays of bio-butanol for engine applications. ASCE J. Energy Eng. 2014, 140, A4014008. [CrossRef]

8. Chen, B.; Liu, X.; Liu, H.; Wang, H.; Kyritsis, D.C.; Yao, M. Soot reduction effects of the addition of four butanol isomers on partially premixed flames of diesel surrogates. Combust. Flame 2017, 177, 123-136. [CrossRef]

9. Labeckas, G.; Slavinskas, S.; Laurinaitis, K. Effect of Jet A-1/Ethanol fuel blend on HCCI combustion and exhaust emissions. ASCE J. Energy Eng. 2018, 144, 04018047. [CrossRef]

10. Valentino, G.; Iannuzzi, S.E.; Marchitto, L.; Merola, S.S.; Tornatore, C. Optical investigation of postinjection strategy effect at the exhaust line of a light-duty diesel engine supplied with diesel/butanol and biodiesel blends. ASCE J. Energy Eng. 2014, 140, A4014010. [CrossRef]

11. Papagiannakis, R.G.; Rakopoulos, D.C.; Rakopoulos, C.D. Theoretical study of the effects of spark timing on the performance and emissions of a light-duty spark ignited engine running under either gasoline or ethanol or butanol fuel operating modes. Energies 2017, 10, 1198. [CrossRef]

12. Kosmadakis, G.M.; Rakopoulos, D.C.; Rakopoulos, C.D. Methane/hydrogen fueling a spark-ignition engine for studying NO, CO and HC emissions with a research CFD code. Fuel 2016, 185, 903-915. [CrossRef]

13. Rakopoulos, C.D.; Michos, C.N.; Giakoumis, E.G. Availability analysis of a syngas fueled spark ignition engine using a multi-zone combustion model. Energy 2008, 33, 1378-1398. [CrossRef]

14. Korakianitis, T.; Namasivayam, A.M.; Crookes, R.J. Natural-gas fuelled spark-ignition (SI) and compression-ignition (CI) engine performance and emissions. Prog. Energy Combust. Sci. 2011, 37, 89-112. [CrossRef]

15. Sahoo, B.B.; Sahoo, N.; Saha, U.K. Effect of engine parameters and type of gaseous fuel on the performance of dual-fuel gas diesel engines-A critical review. Renew. Sustain. Energy Rev. 2009, 13, 1151-1184. [CrossRef]

16. Lee, D.; Lee, C.S. Effects of DME-Isobutane blended fuels on combustion and emissions reduction in a passenger car diesel engine. ASCE J. Energy Eng. 2017, 143, 04017003. [CrossRef] 
17. Singhal, S.; Agarwal, S.; Arora, S.; Sharma, P.; Singhal, N. Upgrading techniques for transformation of biogas to bio-CNG: A review. Int. J. Energy Res. 2017, 41, 1657-1669. [CrossRef]

18. Gaikwad, M.S.; Jadhav, K.M.; Kolekar, A.H.; Chitragar, P.R. Combustion characteristics of biomethane-diesel dual-fueled CI engine with exhaust gas recirculation. Biofuels 2018. [CrossRef]

19. Papong, S.; Rotwiroon, P.; Chatchupong, T.; Malakul, P. Life cycle energy and environmental assessment of bio-CNG utilization from cassava starch wastewater treatment plants in Thailand. Renew. Energy 2014, 65, 64-69. [CrossRef]

20. Ryan, F.; Caulfield, B. Examining the benefits of using bio-CNG in urban bus operations. Transp. Res. Part D 2010, 15, 362-365. [CrossRef]

21. Heywood, J.B. Internal Combustion Engine Fundamentals; McGraw-Hill: New York, NY, USA, 1988.

22. Ferguson, C.R. Internal Combustion Engines-Applied Thermosciences; John Wiley: New York, NY, USA, 1986.

23. Karim, G.A. Combustion in gas fueled compression-ignition engines of the dual fuel type. Trans. ASME J. Eng. Gas Turbines Power 2003, 125, 827-836. [CrossRef]

24. Galal, M.G.; Abdel Aal, M.M.; El Kady, M.A. A comparative study between diesel and dual-fuel engines: Performance and emissions. Combust. Sci. Technol. 2002, 174, 241-256. [CrossRef]

25. Rakopoulos, D.C.; Rakopoulos, C.D.; Giakoumis, E.G.; Papagiannakis, R.G. Evaluating oxygenated fuel's influence on combustion and emissions in diesel engines using a two-zone combustion model. ASCE J. Energy Eng. 2018, 144, 04018046. [CrossRef]

26. Rakopoulos, C.D.; Rakopoulos, D.C.; Mavropoulos, G.C.; Kosmadakis, G.M. Investigating the EGR rate and temperature impact on diesel engine combustion and emissions under various injection timings and loads by comprehensive two-zone modeling. Energy 2018, 157, 990-1014. [CrossRef]

27. Rakopoulos, C.D.; Hountalas, D.T.; Zannis, T.C.; Levendis, Y.A. Operational and environmental evaluation of diesel engines burning oxygen-enriched air or oxygen-enriched fuels: A review. Trans. SAE J. Fuels Lubr. 2004, 113, 1723-1743.

28. Zannis, T.C.; Pariotis, E.G.; Hountalas, D.T.; Rakopoulos, D.C.; Levendis, Y.A. Theoretical study of DI diesel engine performance and pollutant emissions using comparable air-side and fuel-side oxygen addition. Energy Convers. Manag. 2007, 48, 2962-2970. [CrossRef]

29. Ghojel, J.; Hilliard, J.C.; Levendis, J.A. Effect of Oxygen Enrichment on the Performance and Emissions of IDI Diesel Engines; SAE Technical Paper 830245; SAE International: New York, NY, USA, 1983.

30. Inal, F.; Senkan, S.M. Effects of oxygenate additive on polycyclic aromatic hydrocarbons (PAHs) and soot formation. Combust. Sci. Technol. 2002, 174, 1-19. [CrossRef]

31. Miyamoto, N.; Ogawa, H.; Nabi, M.N. Approaches to extremely low emissions and efficient diesel combustion with oxygenated fuels. Int. J. Engine Res. 2000, 1, 71-85. [CrossRef]

32. Rakopoulos, D.C.; Rakopoulos, C.D.; Giakoumis, E.G.; Komninos, N.P.; Kosmadakis, G.M.; Papagiannakis, R.G. Comparative evaluation of ethanol, $n$-butanol, and diethyl ether effects as biofuel supplements on combustion characteristics, cyclic variations, and emissions balance in light-duty diesel engine. ASCE J. Energy Eng. 2017, 143, 04016044. [CrossRef]

33. Rakopoulos, D.C.; Rakopoulos, C.D.; Giakoumis, E.G. Impact of properties of vegetable oil, bio-diesel, ethanol and $n$-butanol on the combustion and emissions of turbocharged HDDI diesel engine operating under steady and transient conditions. Fuel 2015, 156, 1-19. [CrossRef]

34. Giakoumis, E.G.; Rakopoulos, C.D.; Dimaratos, A.M.; Rakopoulos, D.C. Exhaust emissions of diesel engines operating under transient conditions with biodiesel fuel blends. Prog. Energy Combust. Sci. 2012, 38, 691-715. [CrossRef]

35. Giakoumis, E.G.; Rakopoulos, D.C.; Rakopoulos, C.D. Combustion noise radiation during dynamic diesel engine operation including effects of various biofuels blends: A review. Renew. Sustain. Energy Rev. 2016, 54, 1099-1113. [CrossRef]

36. Abd Alla, G.H.; Soliman, H.A.; Badr, O.A.; Abd Rabbo, M.F. Effect of pilot fuel quantity on the performance of a dual fuel engine. Energy Convers. Manag. 2000, 41, 559-572. [CrossRef]

37. Abd Alla, G.H.; Soliman, H.A.; Badr, O.A.; Abd Rabbo, M.F. Effect of injection timing on the performance of a dual fuel engine. Energy Convers. Manag. 2002, 43, 269-277. [CrossRef]

38. Pirouzpanah, V.; Saray, R.K. Reduction of emissions in an automobile direct injection diesel engine dual-fuelled with natural gas by using variable exhaust gas recirculation. Proc. Inst. Mech. Eng. Part D J. Automob. Eng. 2003, 217, 719-725. [CrossRef] 
39. Papagiannakis, R.G.; Hountalas, D.T. Experimental investigation concerning the effect of natural gas percentage on performance and emissions of a DI dual fuel diesel engine. Appl. Therm. Eng. 2003, 23, 353-365. [CrossRef]

40. Papagiannakis, R.G.; Hountalas, D.T. Combustion and exhaust emission characteristics of a dual fuel compression ignition engine operated with pilot diesel fuel and natural gas. Energy Convers. Manag. 2004, 45, 2971-2987. [CrossRef]

41. Singh, S.; Krishnan, S.R.; Srinivasan, K.K.; Midkiff, K.C.; Bell, S.R. Effect of pilot injection timing, pilot quantity, and intake charge conditions on performance and NOx emissions for an advanced low-pilot-ignited natural gas engine. Int. J. Engine Res. 2004, 5, 329-348. [CrossRef]

42. Srinivasan, K.K.; Bell, S.R.; Gong, W.; Fiveland, S.B.; Krishnan, S.R.; Singh, S.; Midkiff, K.C. The advanced injection low pilot ignited natural gas engine: A combustion analysis. Trans. ASME J. Eng. Gas Turbines Power 2006, 128, 213-218. [CrossRef]

43. Poonia, M.P.; Ramesh, A.; Gaur, R.R.; Joshi, A. Effect of pilot fuel quantity, injector needle lift pressure and load on combustion characteristics of an LPG diesel dual fuel engine. Eng. Innov. Technol. 2012, 2, 26-31.

44. Abdelaal, M.M.; Rabee, B.A.; Hegab, A.H. Effect of adding oxygen to the intake air on a dual-fuel engine performance, emissions, and knock tendency. Energy 2013, 61, 612-620. [CrossRef]

45. Cacua, K.; Amell, A.; Cadavid, F. Effects of oxygen enriched air on the operation and performance of a diesel-biogas dual fuel engine. Biomass Bioenergy 2012, 45, 159-167. [CrossRef]

46. Papagiannakis, R.G.; Hountalas, D.T. Theoretical and Experimental Investigation of a Direct Injection Dual Fuel Diesel-Natural Gas Engine; SAE Technical Paper 2002-01-0868; SAE International: New York, NY, USA, 2002.

47. Papagiannakis, R.G.; Hountalas, D.T.; Kotsiopoulos, P.N. Experimental and Theoretical Analysis of the Combustion and Pollutants Formation Mechanisms in Dual Fuel DI Diesel Engines; SAE Technical Paper No. 2005-01-1726; SAE International: New York, NY, USA, 2005.

48. Papagiannakis, R.G. Study of air inlet preheating and EGR impacts for improving the operation of compression ignition engine running under dual fuel mode. Energy Convers. Manag. 2012, 68, 40-53. [CrossRef]

49. Papagiannakis, R.G.; Krishnan, S.R.; Rakopoulos, D.C.; Srinivasan, K.K.; Rakopoulos, C.D. A combined experimental and theoretical study of diesel fuel injection timing and gaseous fuel/diesel mass ratio effects on the performance and emissions of natural gas-diesel HDDI engine operating at various loads. Fuel 2017, 202, 675-687. [CrossRef]

50. Tarabet, L.; Loubar, K.; Lounici, M.S.; Khiari, K.; Belmrabet, T.; Tazerout, M. Experimental investigation of DI diesel engine operating with eucalyptus biodiesel/natural gas under dual fuel mode. Fuel 2014, 133, 129-138. [CrossRef]

51. Selim, M.Y.E.; Radwan, M.S.; Saleh, H.E. Improving the performance of dual fuel engines running on natural gas/LPG by using pilot fuel derived from jojoba seeds. Renew. Energy 2008, 33, 1173-1185. [CrossRef]

52. Banapurmath, N.R.; Tewari, P.G.; Hosmath, R.S. Experimental investigations of a four-stroke single cylinder direct injection diesel engine operated on dual fuel mode with producer gas as inducted fuel and Honge oil and its methyl ester (HOME) as injected fuels. Renew. Energy 2008, 33, 2007-2018. [CrossRef]

53. Korakianitis, T.; Namasivayam, A.M.; Crookes, R.J. Diesel and rapeseed methyl ester (RME) pilot fuels for hydrogen and natural gas dual-fuel combustion in compression-ignition engines. Fuel 2011, 90, $2384-2395$. [CrossRef]

54. Hiroyasu, H.; Kadota, T.; Arai, M. Development and use of a spray combustion modeling to predict diesel engine efficiency and pollutant emissions. Bull. JSME 1983, 26, 569-576. [CrossRef]

55. Blizard, N.C.; Keck, J.C. Experimental and Theoretical Investigation of Turbulent Burning Model for Internal Combustion Engines; SAE Technical Paper 740191; SAE International: New York, NY, USA, 1974.

56. Whitehouse, N.D.; Way, R.J.B. Rate of heat release in diesel engines and its correlation with fuel injection data. Proc. Inst. Mech. Eng. 1969, 184, 17-29. [CrossRef]

57. Benson, R.S.; Whitehouse, N.D. Internal Combustion Engines; Pergamon Press: Oxford, UK, 1979.

58. Annand, W.J.D. Heat transfer in the cylinders of reciprocating internal combustion engines. Proc. Inst. Mech. Eng. 1963, 177, 973-990. 
59. Vickland, C.W.; Strange, F.M.; Bell, R.A.; Starkman, E.S. A consideration of the high temperature thermodynamics of internal combustion engines. Trans. SAE 1962, 70, 785-793.

60. Lavoie, G.A.; Heywood, J.B.; Keck, J.C. Experimental and theoretical study of nitric oxide formation in internal combustion engines. Combust. Sci. Technol. 1970, 1, 313-326. [CrossRef]

(C) 2018 by the authors. Licensee MDPI, Basel, Switzerland. This article is an open access article distributed under the terms and conditions of the Creative Commons Attribution (CC BY) license (http:/ / creativecommons.org/licenses/by/4.0/). 